(C) 2021, The Authors. Published by Elsevier Inc. and Fass Inc. on behalf of the American Dairy Science Association ${ }^{\circledR}$. This is an open access article under the CC BY-NC-ND license (http://creativecommons.org/licenses/by-nc-nd/4.0/).

\title{
Meta-analysis of effects of inoculation with Lactobacillus buchneri, with or without other bacteria, on silage fermentation, aerobic stability, and performance of dairy cows
}

\author{
Kathy G. Arriola, ${ }^{1} \odot$ André S. Oliveira, ${ }^{2} \odot$ Yun Jiang, ${ }^{1} \odot$ Donghyeon Kim, ${ }^{1 *} \odot$ Henrique M. Silva, ${ }^{2} \odot$

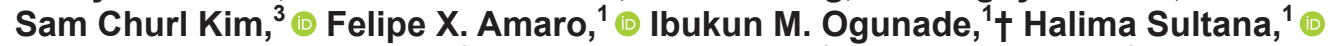

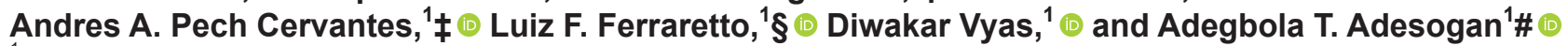 \\ ${ }^{1}$ Department of Animal Sciences, Institute of Food and Agricultural Sciences, University of Florida, Gainesville 32611 \\ 2Dairy Cattle Research Laboratory, Universidade Federal de Mato Grosso, Campus Sinop, Sinop, MT 78557-267, Brazil \\ ${ }^{3}$ Division of Applied Life Science (BK21plus, Institute of Agriculture and Life Sciences), Gyeongsang National University, 52828 South Korea
}

\section{ABSTRACT}

A meta-analysis of 158 peer-reviewed articles was conducted to examine effects of inoculation with Lactobacillus buchneri (LB)-based inoculants (LBB) that did or did not include homolactic or obligate heterolactic bacteria on silage fermentation and aerobic stability. A complementary meta-analysis of 12 articles examined LBB inoculation effects on dairy cow performance. Raw mean differences between inoculant and control treatment means weighted by inverse variance were compared with a hierarchical effects model that included robust variance estimation. Meta-regression and subgrouping analysis were used to identify effects of covariates including forage type, application rate $\left(\leq 10^{4}, 10^{5}, 10^{6}\right.$, or $\geq 10^{7} \mathrm{cfu} / \mathrm{g}$ as fed $)$, bacteria type (LB vs. LB plus other bacteria), enzyme inclusion, ensiling duration, and silo type (laboratory or farm scale). Inoculation with LBB increased acetate (62\%), 1, 2 propanediol $(364 \%)$ and propionate $(30 \%)$ concentration and aerobic stability $(73.8 \%)$ and reduced lactate concentration $(7.2 \%)$, yeast counts (7-fold) and mold counts (3-fold). Feeding inoculated silage did not affect milk yield, dry matter intake, and feed efficiency in lactating dairy cows. However, forage type, inoculant composition, and dose effects on silage quality measures were evident. Inoculation with LBB increased aerobic stability of all silages except tropical grasses. Adding

Received September 15, 2020.

Accepted February 16, 2021.

*Current address: National Institute of Animal Science, RDA, Cheonan, 31000 South Korea.

†Current address: Division of Animal Nutritional Science, West Virginia University, Morgantown 20506.

$\ddagger$ Current address: Agricultural Research Station, Fort Valley State University, Fort Valley, GA 31030.

$\S$ Current address: Department of Animal and Dairy Sciences, University of Wisconsin-Madison, Madison 53706.

\#Corresponding author: adesogan@ufl.edu obligate homolactic or facultative heterolactic bacteria to LB prevented the small increase in DM losses caused by LB alone. The $10^{5}$ and $10^{6} \mathrm{cfu} / \mathrm{g}$ rates were most effective at minimizing DM losses while aerobic stability was only increased with $10^{5}, 10^{6}$, and $\geq 10^{7} \mathrm{cfu} / \mathrm{g}$ rates. Inoculation with LBB increased acetate concentration, reduced yeast counts and improved aerobic stability but did not improve dairy cow performance.

Key words: corn silage, heterolactic bacteria, Lactobacillus buchneri, Lactobacillus hilgardii

\section{INTRODUCTION}

Silage is an integral component of most dairy cow diets in the United States and several other countries throughout the world, and previous research has been focused on developing strategies to improve silage quality and minimize nutrient losses during ensiling (Wilkins, 2003; Wilkinson et al., 2003). Silage inoculants have been the most commonly used additive for improving silage quality (Kung, 1998). Our recent meta-analysis showed that inoculation with homolactic and facultative heterolactic lactic acid bacteria (LAB) improved the fermentation of grass and legume silages and the performance of dairy cows but did not affect the fermentation of whole-plant corn, whole-plant sorghum, and sugarcane silages or aerobic stability of any silage (Oliveira et al., 2017). This meta-analysis (Oliveira et al., 2017) was only focused on inoculants for improving silage fermentation; hence, it intentionally excluded obligate heterolactic LAB that are added to improve aerobic stability. Among such obligate bacteria, only a few have been evaluated for their effects on silage fermentation and aerobic stability and these are primarily from the Lactobacillus buchneri (LB) group of the Lactobacillus genus; they include primarily L. buchneri and much less commonly Lactobacillus brevis, Lactobacillus diolivorans, Lactobacillus hilgardii, Lactobacillus kefiri, 
and Lactobacillus parafarraginis (Muck et al., 2018). Lactobacillus buchneri improved the aerobic stability of silages in various laboratory studies (Muck, 1996; Weinberg et al., 1999; Arriola et al., 2011a) and field studies (Mari et al., 2009; Kristensen et al., 2010) in a strain- (Tabacco et al., 2011) and dose- (Driehuis et al., 1999; Ranjit and Kung, 2000) dependent manner. This effect of LB was confirmed by the meta-analysis of Kleinschmit and Kung (2006) in which aerobic stability of untreated corn silage $(25 \mathrm{~h})$ was increased to $35 \mathrm{~h}$ when inoculated with $\mathrm{LB}$ at or below $1 \times 10^{5} \mathrm{cfu} / \mathrm{g}$ and to $503 \mathrm{~h}$ at more than $1 \times 10^{5} \mathrm{cfu} / \mathrm{g}$. This aerobic stability improvement by LB has been attributed to its ability to convert lactate into acetate and 1,2 propanediol under anaerobic conditions (Oude Elferink et al., 2001), and the corresponding reduction in yeast and mold counts due to the antifungal attribute of acetate (Driehuis et al., 2001). Similarly to L. diolivorans (Krooneman et al., 2002) and Lactobacillus reuteri (Sriramulu et al., 2008), a novel strain of L. buchneri A KKP 2047 p, was recently reported to convert 1,2 propanediol into propionate (Zielińska et al., 2017) in the presence of cobalamine, potentially conferring greater antifungal effects. However, it is uncertain if naturallyoccurring LB strains have this property (Muck et al., 2018), which may enhance aerobic stability even further due to the combined antifungal of effects of propionate and acetate.

Earlier studies suggested that forage inoculation with heterolactic bacteria such as LB may increase DM losses during ensiling (Ranjit and Kung, 2000), and this was confirmed by the 1 to $1.8 \%$ increase reported when LB was applied to corn, grass, and small grain forages at high $\left(>1 \times 10^{5} \mathrm{cfu} / \mathrm{g}\right)$ doses in the meta-analysis of Kleinschmit and Kung (2006), though no effect was detected at lower doses $\left(\leq 1 \times 10^{5} \mathrm{cfu} / \mathrm{g}\right)$. The small increases in DM losses can be readily accepted if accompanied by substantial increases in aerobic stability (Kleinschmit and Kung, 2006). Nevertheless, to avoid or reduce DM losses and to enhance fermentation simultaneously, several inoculants now contain a mixture of homolactic or facultative heterolactic bacteria with obligate heterolactic bacteria. Studies have demonstrated that combining homolactic bacteria with LB improved aerobic stability without affecting DM losses (Driehuis et al., 2001; Jatkauskas and Vrotniakiene, 2011; Arriola et al., 2015).

Based on studies indicating associations between ingestion of acetate and reductions in DMI, (BuchananSmith, 1990; Gherardi and Black, 1991), concerns have been expressed that inoculating forages with LB and the attendant increases in acetate concentration may reduce feed intake in dairy cows (Kleinschmit and Kung, 2006). However, this has not been consistently supported in dairy cow studies. Several studies reported that LB did not affect intake (Taylor et al., 2002; Kung et al., 2003; Arriola et al., 2011b) or milk yield (Taylor et al., 2002; da Silva et al., 2017), whereas others reported an increase in milk yield (Kung et al., 2003; Ben-Meir et al., 2018).

The objective of the present study was to examine effects of inoculation with LB-based bacteria (LBB), including LB alone or LB with homolactic or obligate heterolactic LAB, on silage fermentation, aerobic stability, and animal performance. We hypothesized that LBB inoculants would improve silage quality, aerobic stability, and milk yield but no effects would be observed on DMI.

\section{MATERIALS AND METHODS}

\section{Literature Search}

A literature search was conducted to evaluate the effects of LB alone or with obligate heterolactic or homolactic LAB on silage fermentation, aerobic stability, and milk production. Peer-reviewed articles published from 1997 to 2020 were searched using the terms "silage" and "Lactobacillus buchneri," using the Web of Science, Google Scholar, and Commonwealth Agricultural Bureaux International Abstracts databases (https: //apps.webofknowledge.com, https://scholar.google .com, https://www.cabi.org/publishing-products/cab -abstracts/). In addition to these terms, "dairy cows" was included in the search for studies on effects of LB inoculants on dairy cow performance. Additional requests were made to individual authors of articles to identify data that might have been collected but not reported in the published paper.

\section{Inclusion Criteria}

Suitability for inclusion was determined initially by reading the abstract to ensure the experiment involved using LB with or without other bacteria to improve silage preservation. The materials and methods portion of the article was then read to exclude experiments that did not meet the inclusion criteria.

The inclusion criteria for selecting studies were as follows: studies had to (1) be published in Englishlanguage peer-reviewed journals, (2) be published after 1996, when the first article (Muck, 1996) on using LB for silage preservation was published, (3) have concurrently examined uninoculated and inoculated treatment groups, (4) have treatments of LB alone without or with other LAB, (5) have used at least $30 \mathrm{~d}$ of ensiling to ensure the silage was properly preserved, (6) have reported the inoculant application rate, (7) have used 
temperature change to measure aerobic stability, which is the most common practice, and (8) have reported either standard error of the mean (SEM) or standard deviation (SD). The inclusion criteria for selecting studies that analyzed the effect of LB with or without other $\mathrm{LAB}$ on the performance of dairy cows were as follows: (1) was published in English-language peer-reviewed journals, (2) concurrently examined uninoculated and inoculated treatment groups, (3) included treatments comprising LB alone without or with other LAB, (4) use randomized design experiments with individual feeding of inoculated and inoculated silage-based diets to cows (5) reported either SEM or SD for the estimation of variance.

\section{Data Extraction}

Silage Quality. Figure 1 Shows a PRISMA diagram (Moher et al., 2009) depicting the data collection process for the meta-analysis. After initial screening, 295 full-text articles were assessed to determine their eligibility to be included in the meta-analysis and 137 articles were excluded for the following reasons: (1) no proper control used in the study (11 experiments); (2) no application rate of inoculants reported (15 experiments); (3) no SEM or SD reported (35 experiments); (4) LB was not one of the treatments (58 experiments); (5) chemical additives were used with LB (2 experiments); and (6) forages were ensiled for less than $30 \mathrm{~d}$ (16 experiments). Based on the inclusion criteria, 158 peer-reviewed papers (up to 542 comparisons) were selected to analyze LB inoculation effects on silage quality, and these were classified by first author, publication, and reference. Additional classifications included forage type [whole-plant corn, whole-plant sorghum, temperate grass, tropical grass, sugarcane, alfalfa, other legumes, grain, high moisture corn (HMC), and other forages]; LAB group $\{\mathrm{LB}$ alone or with homolactic LAB [Lactobacillus plantarum $(\mathbf{L B}+\mathbf{L P})$, Pediococcous pentosaceus $(\mathbf{L B}+\mathbf{P P})$, Lactobacillus plantarum and Pediococcus pentosaceus $(\mathbf{L B}+\mathbf{L P}+\mathbf{P P})$, Lactobacillus plantarum and Enterococcus faecium $(\mathbf{L B}+\mathbf{L P}+\mathbf{E F})]$, LB plus other species such as Lactococcus lactis, Lactobacillus casei, Pediococcus acidilactici (LB+others), or obligate heterolactic [LAB Lactobacillus hilgardii $(\mathbf{L B}+\mathbf{L H})]\} ; \mathrm{LAB}$ application rate $\left(\leq 10^{4}, 10^{5}, 10^{6}\right.$ or $\geq 10^{7} \mathrm{cfu} / \mathrm{g}$ fresh forage); silo type (laboratory or farm scale), and whether or not the inoculant contained enzymes.

The number of replicates, means, and SEM were extracted for the following response variables from both control and inoculant treatments: $\mathrm{pH}, \mathrm{DM}$ recovery, concentrations of DM, NDF, CP, water-soluble carbohydrate (WSC), ethanol, 1,2 propanediol, lactate, ac- etate, propionate, and butyrate, counts of LAB, yeast, and mold (log cfu/g fresh forage), and aerobic stability (h). The data set to evaluate silage quality measurements and corresponding references are presented in Supplemental Table S1 (https://doi.org/10.7910/ DVN/JQNWW6) and Supplemental File S1 (https:// doi.org/10.7910/DVN/BVNRA1), respectively.

Dairy Cow Performance. The database search for dairy cow performance in response to feeding LBB-inoculated silage retrieved 48 studies. A total of 32 studies were excluded because animals were not fed inoculated and uninoculated silage-based diets, 2 studies were excluded due to lack of a proper control treatment, 1 study was excluded because no SEM or SD was reported, and 1 study did not use LB as a treatment. Based on the inclusion criteria, 13 comparisons from 12 peer-reviewed studies were selected as shown in the PRISMA diagram for studies selected to examine the milk production response to inoculation (Figure 2). Studies were classified by first author, publication reference, forage type (whole-plant corn and other forages such as wheat, sugarcane, alfalfa, barley), LAB species (LB alone or with other LAB), LAB application rate $\left(10^{5}, 10^{6}\right.$, and $10^{7} \mathrm{cfu} / \mathrm{g}$ as fed $)$, and level of milk yield of the control cows (a median milk yield of $<31.7 \mathrm{~kg} / \mathrm{d}$ or $\geq 31.7 \mathrm{~kg} / \mathrm{d}$ ). The number of replicates, means, and SEM were extracted from response variables for control and inoculated treatments: unadjusted milk yield, DMI, feed efficiency, milk fat and protein concentrations, and total-tract DM digestibility. The data set to evaluate the dairy cow performance response and corresponding references are presented in Supplemental Table S2 (https://doi.org/10.7910/DVN/WYOURO) and Supplemental File S1 (https://doi.org/10.7910/ DVN/BVNRA1), respectively.

\section{Statistical Analysis}

Effect Size. The effects of inoculating LBB on silage quality and performance of dairy cows were evaluated using weighted raw mean differences (WMD) between uninoculated and inoculated silage means (estimated effect size). Weighting was performed by the inverse of the variance in a hierarchical effects model that included robust variance estimation, as proposed by Tipton (2015).

Heterogeneity. Variations among treatment level WMD were assessed using the $I^{2}$ statistic (Higgins et al., 2003), which measures the effect of heterogeneity on a meta-analysis [i.e., the proportion of true variance effects of the treatment (indicated by the $\tau 2$ statistic) divided by the total variance observed in a treatment (Borenstein et al., 2017; Lean et al., 2018)]. The $\tau 2$ statistic has also been described as the between-cluster 
variance component, whereas the $\Omega^{2}$ statistic represents the between-studies-within-cluster variance component (Hedges et al., 2010; Fisher et al., 2017). All 3 statistics are provided to allow readers to evaluate them.

Meta-Regression and Subgrouping. Meta-regression analysis was used to identify effects of the covariates (forage type, application rate, enzyme use, days of ensiling, LAB group, and silo type) on the LBB inoculation response for silage quality, using WMD as the dependent variable. The meta-regression analysis was performed using the robust variance estimation method with a hierarchical effects model (Tipton, 2015). In addition, subgrouping of the WMD was analyzed to evaluate the effects of the covariates on LBB inoculation response (WMD), as shown earlier (Oliveira et al., 2017).
Weighting. Each variance comparison between inoculant and control treatments was calculated as square of the pooled SD (Vesterinen et al., 2014). The SD for the inoculant and control for each comparison was calculated from $\mathrm{SEM}$ reported, where $\mathrm{SD}=\mathrm{SEM} \times \sqrt{n}$, where $n=$ number of experimental units. When the standard deviation of the difference (SED) was reported in studies, SEM was calculated as: $\mathrm{SEM}=\mathrm{SED} / \sqrt{2}$. To prevent overweighting of studies with extremely low SEM, we truncated (i.e., trimmed) the SEM as shown earlier (Roman-Garcia et al., 2016). For the fermentation data set, SEM $<(0.25 \times$ mean SEM) was trimmed to one-fourth of the mean SEM, such that the following percentages of parameter estimates were trimmed: $\mathrm{pH}(23 \%)$, aerobic stability (19\%),

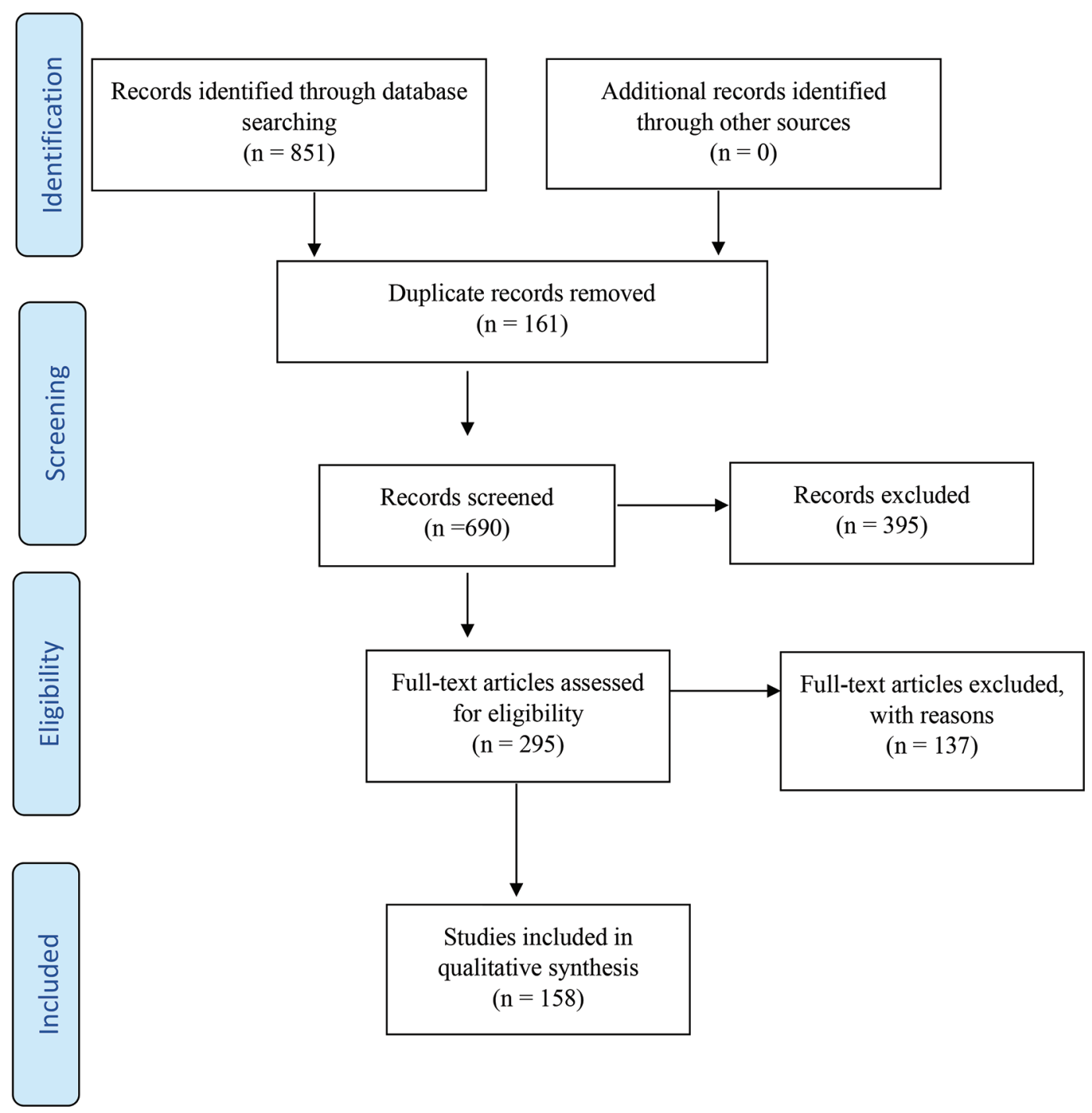

Figure 1. The PRISMA flow diagram from initial search and screening to final selection of studies included for the meta-analysis on the effect of Lactobacillus buchneri with or without homolactic or obligate heterolactic bacteria on silage fermentation and aerobic stability. 


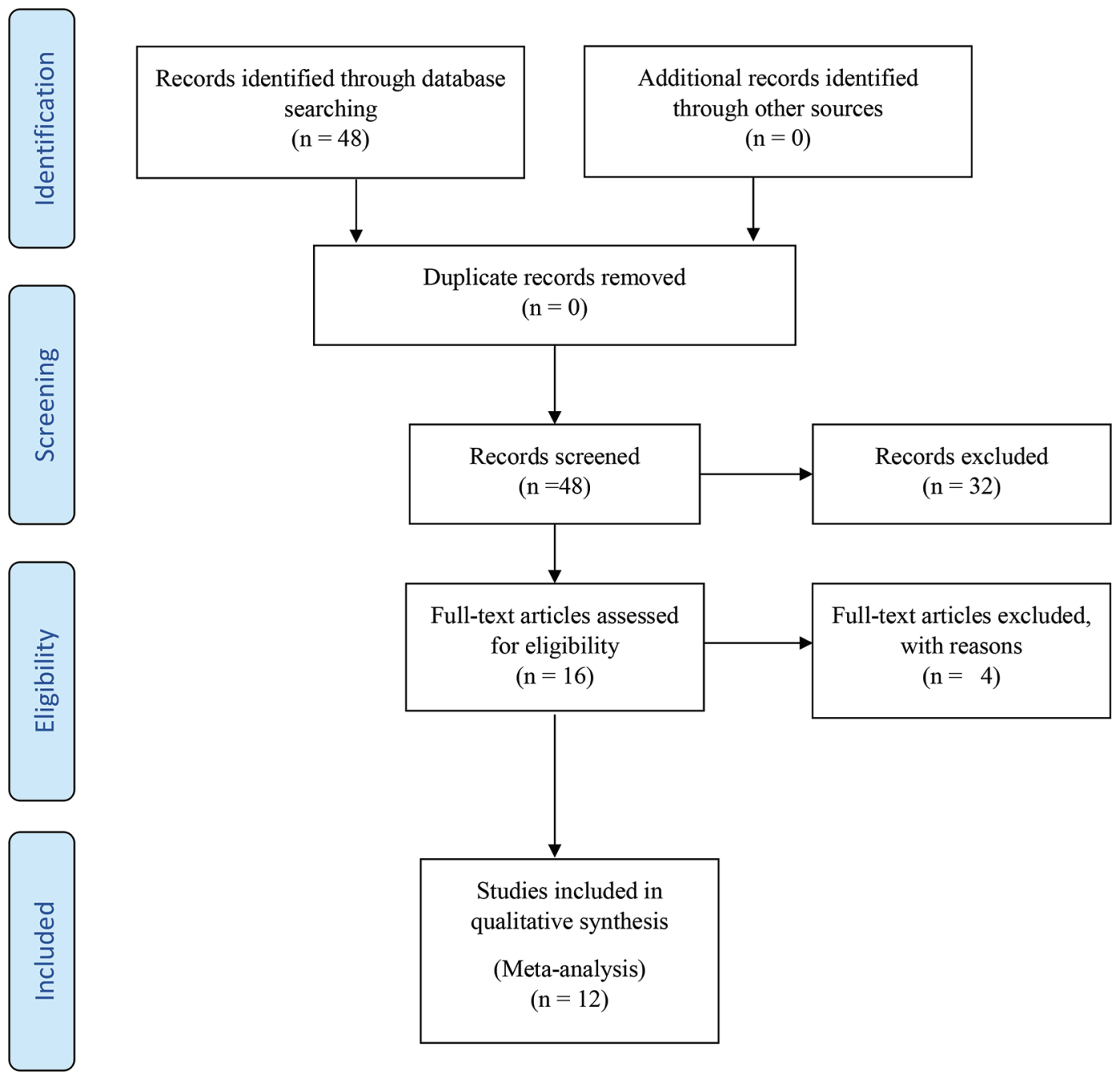

Figure 2. The PRISMA flow diagram from initial search and screening to final selection of studies included for the meta-analysis on the effect of Lactobacillus buchneri with or without homolactic or obligate heterolactic bacteria on dairy production.

DM recovery (24\%), DM (18\%), CP (19\%), NDF (17\%), lactate $(15 \%)$, acetate $(19 \%)$, propionate $(22 \%)$, butyrate $(37 \%)$, ethanol (40\%), 1,2 propanediol $(23 \%), \mathrm{NH}_{3-}$ $\mathrm{N}(29 \%)$, WSC $(36 \%)$, yeast $(31 \%)$, mold $(38 \%)$, and $\mathrm{LAB}$ account $(50 \%)$. For the dairy cow performance data set, the SEM $<(0.50 \times$ mean SEM $)$ was trimmed at half of the mean SEM: DMI (11\% of observations), feed efficiency (25\%), milk yield (20\%), milk fat content $(30 \%)$, milk protein content $(33 \%)$, milk lactose content $(29 \%)$, milk fat yield $(0 \%)$, milk protein yield $(0 \%)$, milk lactose yield $(0 \%)$, and DM-total-tract digestibility $(0 \%)$. This trimming process was done separately for mixed and fixed effects models because mixed models tend to have higher SEM (Littell et al., 1998).

Publication Bias and Outlier Analysis. Publication bias was examined using funnel plot (Light and Pillemer, 1984) plot asymmetry and by Egger`s regression method (Egger et al., 1997). Comparisons between uninoculated and inoculated treatments with standardized residuals $>2.5$ or $<-2.5$, and with Cook's distances (Cook, 1977) $>5 / n$ were removed (Oliveira et al., 2017).

Statistical Packages. The robumeta package (Fisher et al., 2017) of RStudio (version 1.3.1093; https:// cran.r-project.org/web/packages/robumeta/robumeta .pdf) was used for overall WMD, forest plot, and metaregression analysis. The metafor package (Viechtbauer, 2010) of R Software (version 1.3.1093; https://cran.r -project.org/web/packages/metafor) was used for subgrouping, publication bias, and outlier analysis. Significance was declared at $P \leq 0.05$ and tendencies at 0.05 $<P \leq 0.10$. 
Table 1. Effect of Lactobacillus buchneri (LB) with or without homolactic or obligate heterolactic bacteria on chemical composition, fermentation characteristics, and microbial count of ensiled forages

\begin{tabular}{|c|c|c|c|c|c|c|c|c|}
\hline Item $^{1}$ & $\mathrm{n}^{2}$ & $\begin{array}{l}\text { Control mean } \\
\text { (SD) }\end{array}$ & \multicolumn{2}{|l|}{$\mathrm{WMD}^{4}(95 \% \mathrm{CI})$} & \multicolumn{2}{|c|}{ Variance component ${ }^{5}$} & $\begin{array}{c}I^{2} \\
(\%)^{6}\end{array}$ & $\begin{array}{c}\text { Funnel test } \\
(P \text {-value })\end{array}$ \\
\hline $\mathrm{DM}, \%$ & 474 & $34.7(14.1)$ & $-0.14(-0.31,0.03)$ & 0.11 & 0.13 & 0.61 & 90.4 & 0.16 \\
\hline DM recovery, \% & 142 & $93.8(5.52)$ & $-0.36(-1.04,0.32)$ & 0.23 & 0.00 & 4.77 & 0.00 & 0.58 \\
\hline $\mathrm{NDF}, \%$ of $\mathrm{DM}$ & 225 & $46.9(14.4)$ & $0.42(0.05,0.79)$ & 0.03 & 0.59 & 0.53 & 81.5 & 0.86 \\
\hline $\mathrm{CP}, \%$ of DM & 243 & $10.3(4.54)$ & $0.014(-0.07,0.10)$ & 0.74 & 0.00 & 0.10 & 76.7 & 0.003 \\
\hline Lactate, $\%$ of DM & 483 & $4.30(2.51)$ & $-0.31(-0.51,-0.11)$ & 0.003 & 0.55 & 0.51 & 97.8 & 0.004 \\
\hline Acetate, $\%$ of DM & 494 & $1.70(1.34)$ & $1.05(0.83,1.27)$ & $<0.01$ & 0.68 & 0.80 & 99.3 & 0.38 \\
\hline Propionate, $\%$ of DM & 233 & $0.27(0.40)$ & $0.083(0.04,0.13)$ & $<0.01$ & 0.00 & 0.13 & 99.7 & 0.46 \\
\hline Butyrate, $\%$ of DM & 164 & $0.28(0.59)$ & $-0.027(-0.05,-0.002)$ & 0.03 & 0.004 & 0.002 & 89.4 & 0.63 \\
\hline Ethanol, \% of DM & 296 & $1.45(2.80)$ & $0.048(-0.03,0.13)$ & 0.23 & 0.05 & 0.00 & 93.5 & 0.02 \\
\hline 1,2 Propanediol, $\%$ of DM & 100 & $0.22(0.34)$ & $0.80(0.39,1.22)$ & 0.001 & 0.49 & 0.28 & 99.7 & 0.35 \\
\hline $\mathrm{LAB}, \log \mathrm{cfu} / \mathrm{g}$ & 236 & $7.18(1.35)$ & $0.60(0.4,0.80)$ & $<0.01$ & 0.00 & 3.20 & 93.4 & 0.49 \\
\hline
\end{tabular}

${ }^{1} \mathrm{WSC}=$ water-soluble carbohydrate; $\mathrm{LAB}=$ lactic acid bacteria.

${ }^{2} \mathrm{n}=$ number of comparisons of inoculated and uninoculated treatments.

${ }^{3}$ Uninoculated treatment.

${ }^{4} \mathrm{WMD}=$ weighted raw mean differences between LB-inoculated and uninoculated treatments, calculated using a robust regression hierarchical model to account for nesting of treatments within study (Tipton, 2015)

${ }^{5} \tau^{2}=$ between-cluster variance component; $\Omega^{2}=$ between-studies-within-cluster variance component (Hedges et al., 2010; Fisher et al., 2017).

${ }^{6} I^{2}=$ proportion of total variation of size effect estimates that is due to heterogeneity.

${ }^{7}$ Egger's regression asymmetry test (Egger et al., 1997).

\section{RESULTS}

Data from 158 peer-reviewed studies were collected to investigate the effects of inoculation of LBB on silage fermentation and aerobic stability of whole-plant corn (38.2\% of the studies), whole-plant sorghum (6.1\%), temperate grass $(17.2 \%)$, tropical grass $(3.3 \%)$, sugarcane $(4.2 \%)$, alfalfa $(6.6 \%)$, other legumes $(1.1 \%)$, grain $(1.3 \%)$, HMC $(7.9 \%)$, and other forages $(14 \%)$. The most common application rates for LBB inoculation were $10^{5}$ and $10^{6} \mathrm{cfu} / \mathrm{g}$ fresh forage, and these represented 60.3 and $29.5 \%$ of the selected studies, respectively. A total of $57.7 \%$ of the studies evaluated the effect of inoculation of LB alone, and combinations of $\mathrm{LB}+\mathrm{PP}, \mathrm{LB}+$ other, or $\mathrm{LB}+\mathrm{LP}$ represented 8.3, 11.8, and $8.9 \%$ of studies, respectively. Most of the studies used laboratory silos (96.3\%), and only a small portion used farm-scale silos (3.7\%). Enzymes were included with inoculants for only $19.6 \%$ of the studies.

\section{Inoculation Effects on Silage Quality}

Overall, LBB inoculation increased silage $\mathrm{pH}$ $(+1.43 \% ; P<0.01)$ and NDF concentration $(+0.90 \%$; $P=0.03)$, whereas no effects were observed on DM recovery $(P=0.23$; Table 1$)$. Water-soluble carbohydrate
$(-12.9 \% ; P<0.01)$, butyrate $(-9.64 \% ; P=0.03)$, and lactate concentrations $(-7.21 \% ; P<0.01)$ were reduced, whereas acetate $(+61.8 \% ; P<0.01)$, propionate $(+30.7 \% ; P<0.01)$, and 1,2 propanediol $(+364 \% ; P<$ $0.01)$ concentrations were increased with LBB inoculation. The LAB counts were increased 4 -fold $(P<0.01)$, yeast counts decreased 7 -fold $(P<0.01)$, and mold counts decreased 3-fold $(P<0.01)$ with LBB inoculation resulting in markedly greater aerobic stability $(+73.8 \% ; P<0.01)$.

Based on the results from the meta-regression analysis (Table 2), forage type, application rate, enzyme inclusion, days of ensiling, and silo type contributed to the variability of some variables. Forage type reduced mold counts $(P=0.05)$ and acetate concentration (tendency, $P=0.09$ ). Application rate tended to reduce $\mathrm{NH}_{3}-\mathrm{N}(P=0.05)$, butyrate $(P=0.05)$, and ethanol $(P=0.06)$ concentrations. Enzyme inclusion in the inoculant tended to reduce $\mathrm{CP}$ concentration $(P$ $=0.09)$, whereas days of ensiling increased LAB $(P$ $<0.01)$ and tended to reduce $\mathrm{CP}(P=0.07)$ concentration and yeast counts $(P=0.06)$. Species of LBB increased WSC $(P=0.03)$, lactate concentration $(P=$ $0.04)$ and reduced acetate concentration $(P<0.01)$, whereas silo type increased DM \% $(P=0.04)$, reduced DM recovery $(P<0.01)$ and mold counts $(P=0.02)$, 


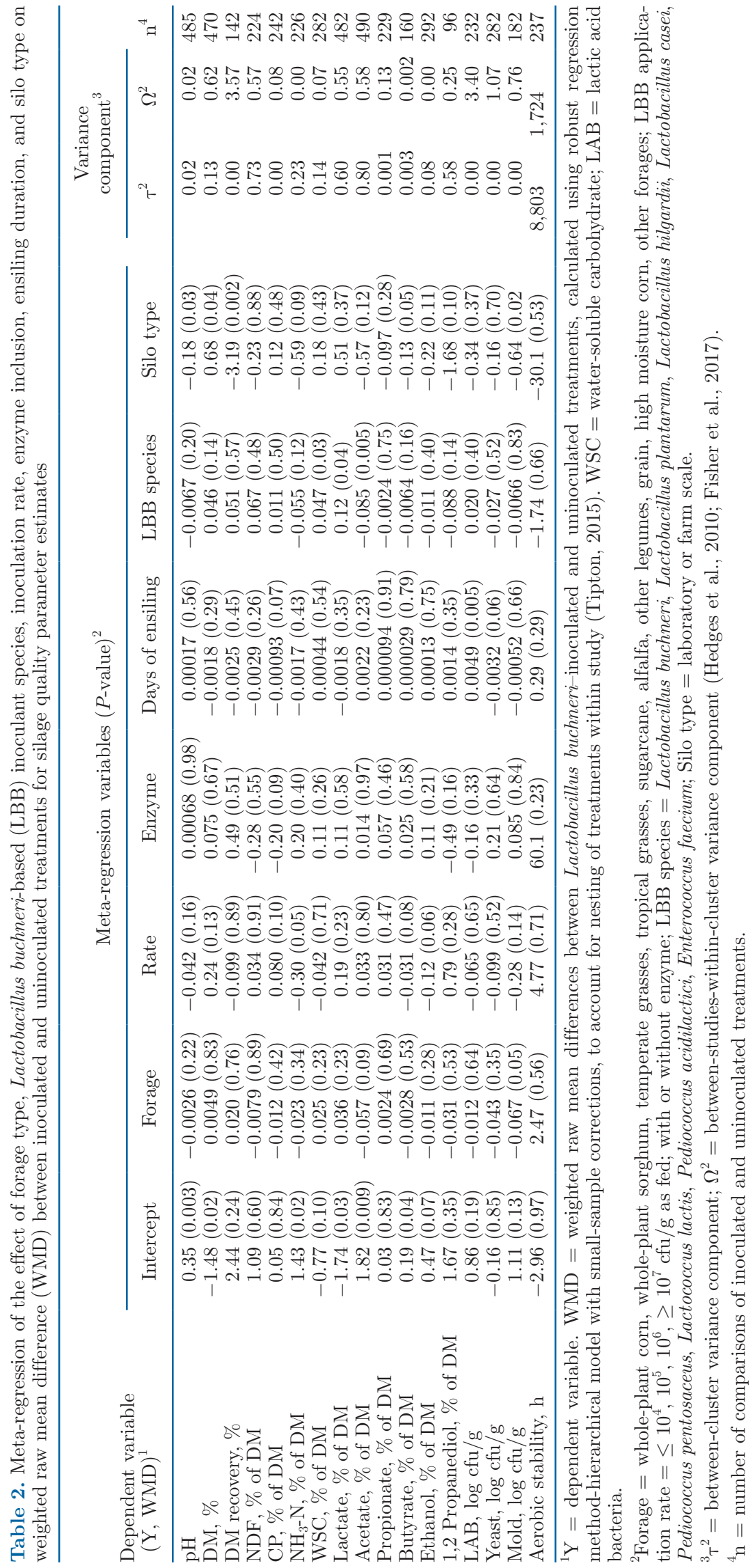


and tended to reduce butyrate $(P=0.05)$ and $\mathrm{NH}_{3}-\mathrm{N}$ $(P=0.09)$ concentration.

The ensuing sections discuss the most important sources of variation from the meta-regression and subgrouping analysis for understanding the LBB inoculation responses. The effects of covariates including forage type (Figure 3), type of LBB species (Figure 4), and inoculation rate (Figure 5) on DM recovery, acetate and 1,2 propanediol concentrations, mold counts, yeast counts, and aerobic stability are presented in the main body of the article, whereas effects of the respective covariates on $\mathrm{pH}$, lactate, propionate, and ethanol are presented in the supplemental section (Supplemental Figures S1, S2, S3, https://doi.org/10.7910/DVN/ ANYKJ5). The effects of ensiling duration on aerobic stability and yeast counts (Figure 6) and that of silo type on mold counts (Figure 7) are presented but their other effects are not shown as they represented only a few studies or were considered less important for understanding the LBB response.
A

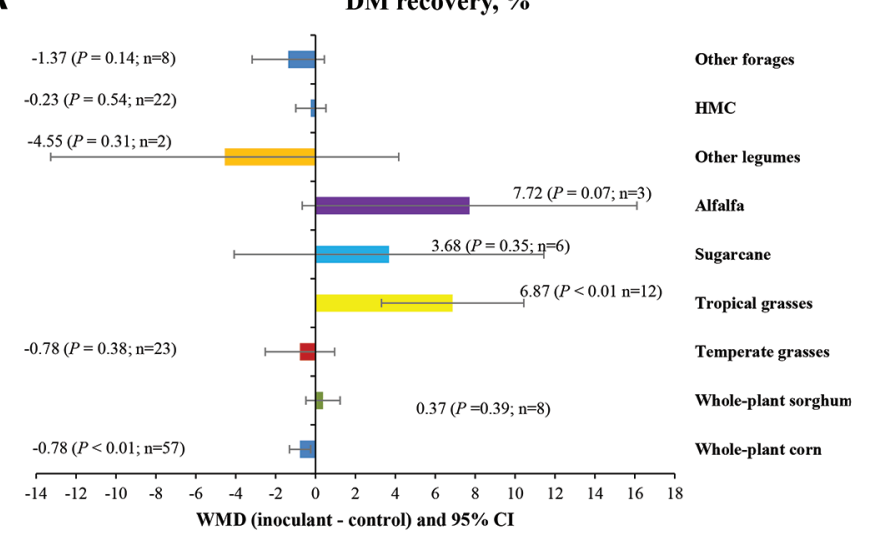

C

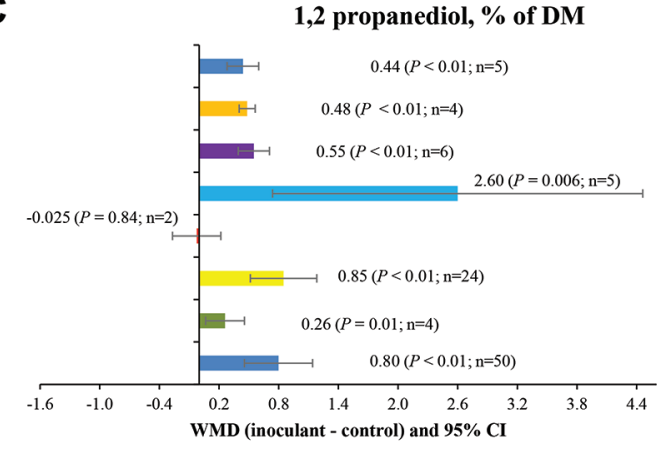

E

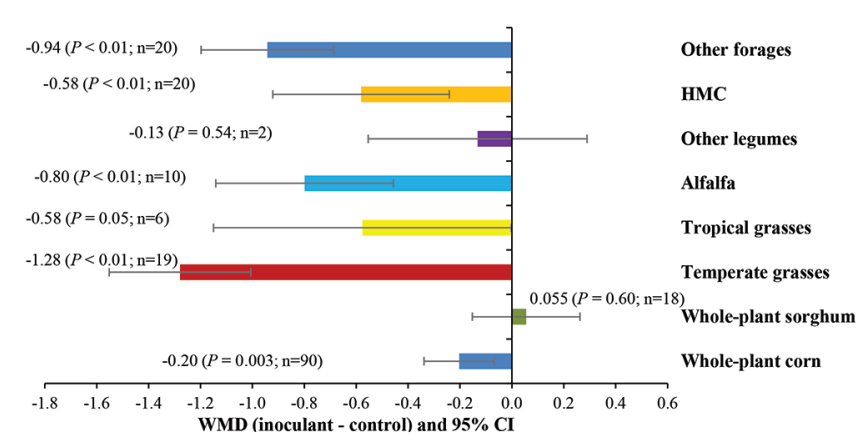

B

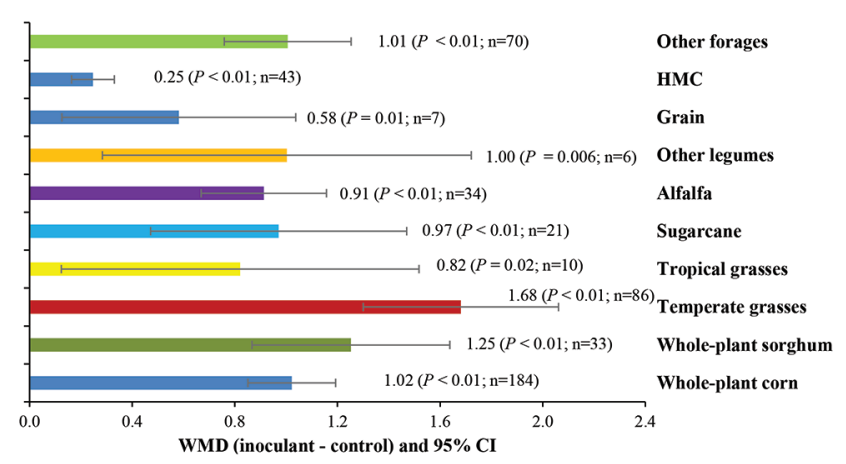

D

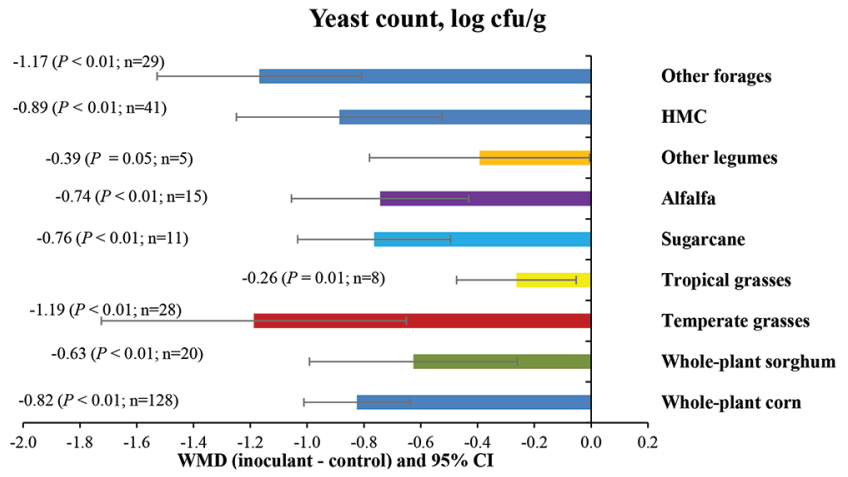

$\mathbf{F}$

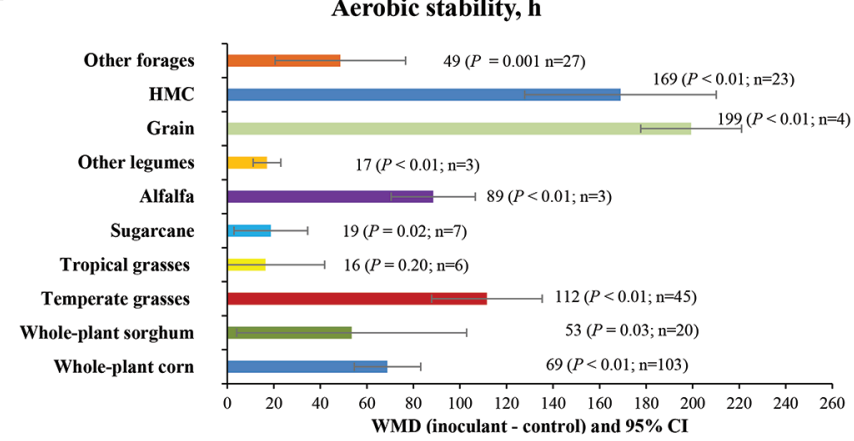

Figure 3. Forage type (subgroup A to F) effect on silage fermentation and aerobic stability responses to inoculation with Lactobacillus buchneri (LB)-based inoculants (LBB) with or without homolactic or obligate heterolactic bacteria. WMD = weighted raw mean differences between LB-inoculated and uninoculated silage. $\mathrm{HMC}=$ high moisture corn; other forages = pea-wheat, rice, triticale, clover-ryegrass, alfalfa-ryegrass, oat, potato-wheat, sweet potato, potato hash. Error bars represent the confidence interval (95\%). 


\section{Effect of Forage Type on the Inoculation Response}

Inoculation with LBB increased the $\mathrm{pH}$ of all silages $(P<0.01)$ except $(P>0.10)$, temperate grasses, sugarcane, alfalfa, and grains (Supplemental Figure S1a) but reduced the $\mathrm{pH}$ of tropical grasses $(P=0.02)$. Inoculation with LBB reduced DM recovery of wholeplant corn silage $(0.78$ percentage points; $P<0.01$;
Figure $3 \mathrm{~A})$ but increased those of tropical grasses (6.87 percentage points; $P=0.01)$ and alfalfa $(P=0.07$, tendency) without affecting others $(P>0.10)$.

Inoculation with LBB reduced lactate concentration $(P<0.05)$ of most forage types except temperate grasses $(P=0.11)$, tropical grasses $(P=0.22)$, alfalfa $(P=0.35)$, and other forages $(P=0.13$; Supplemental Figure S1b). Acetate concentration was greater with
A

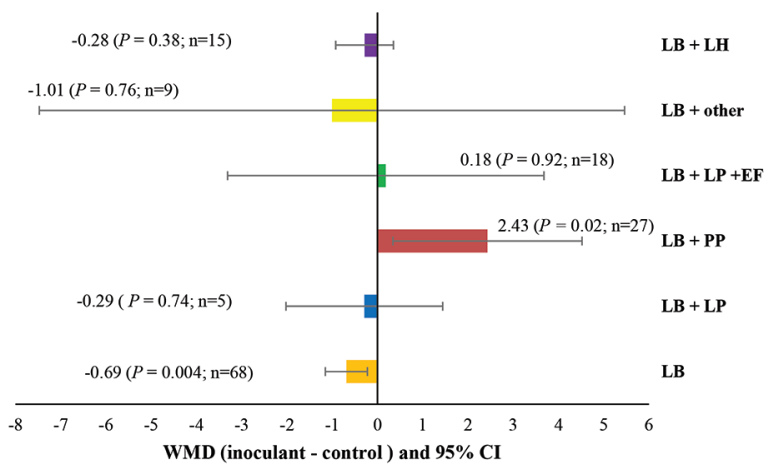

C

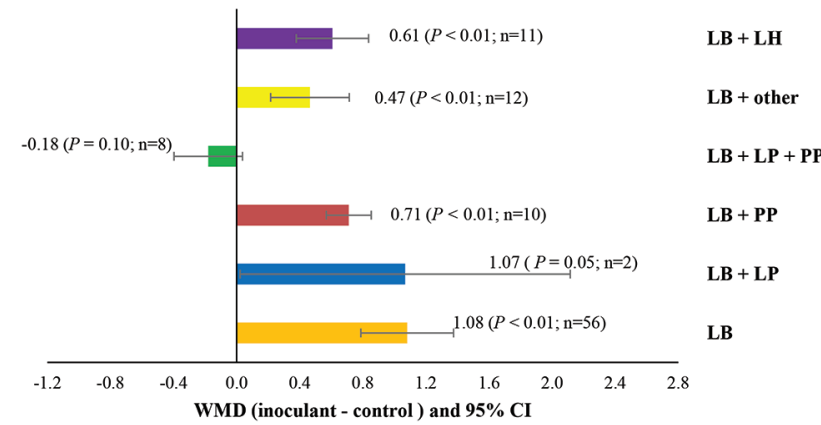

$\mathbf{E}$

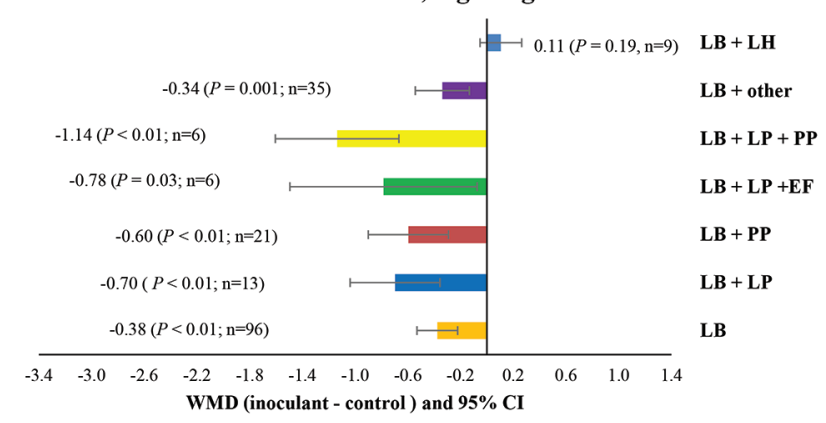

B

Acetate, \% of DM

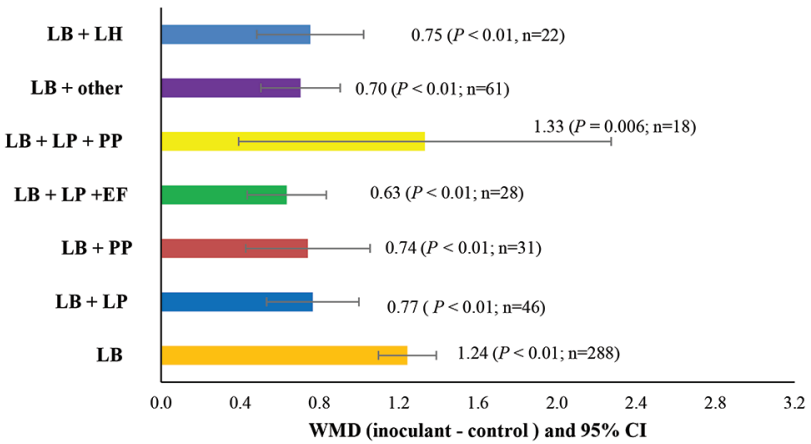

D

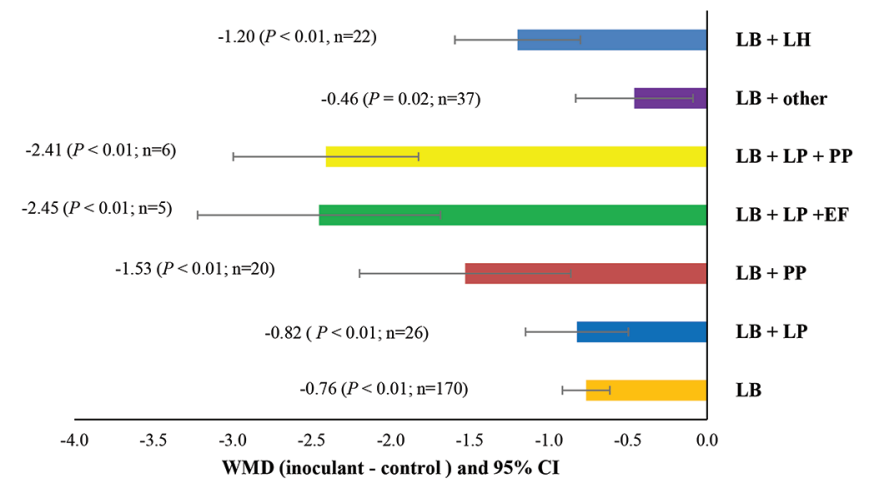

$\mathbf{F}$

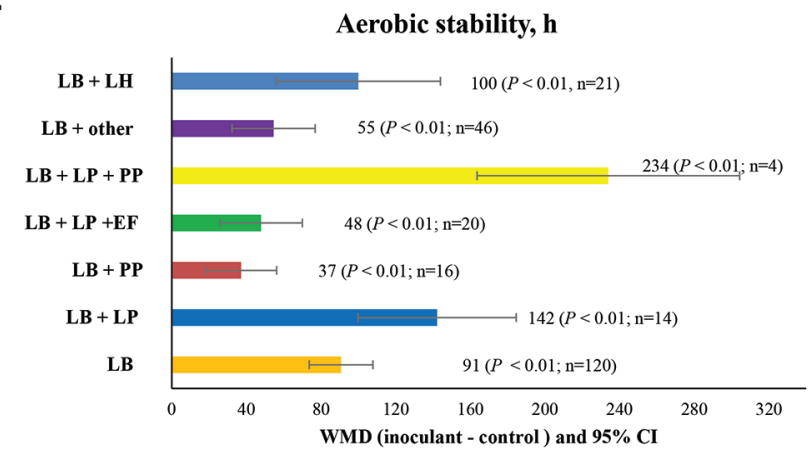

Figure 4. Lactic acid bacteria type (subgroups A to F) effects on silage fermentation and aerobic stability responses to inoculation with Lactobacillus buchneri (LB)-based inoculants (LBB) with or without homolactic or obligate heterolactic bacteria. WMD = weighted raw mean differences between LB-inoculated and uninoculated silage; LB = Lactobacillus buchneri alone; LB $+\mathrm{LP}=$ L. buchneri with Lactobacillus plantarum, $\mathrm{LB}+\mathrm{PP}=$ L. buchneri with Pediococcous pentosaceus; $\mathrm{LB}+\mathrm{LP}+\mathrm{EF}=$ L. buchneri with L. plantarum and Enterococcus faecium; $\mathrm{LB}+\mathrm{LP}+\mathrm{PP}=$ L. buchneri with L. plantarum and P. pentosaceous; $\mathrm{LB}+\mathrm{LH}=$ L. buchneri with Lactobacillus hilgardii $; \mathrm{LB}+\mathrm{other}=$ L. buchneri with other species such as Lactococcus lactis, Lactobacillus casei, Pediococcus acidilactici. Error bars represent the confidence interval (95\%). 
LBB inoculation $(P<0.05)$ in all forage types; however, effects were less pronounced for HMC (Figure 3B). Lactobacillus buchneri-based bacteria inoculation increased propionate concentration $(P<0.01)$ for whole-plant corn silage, temperate grasses, and other forages silage, whereas no effect was observed on HMC, grain, alfalfa, sugarcane, tropical grasses, and whole-plant sorghum silage $(P>0.10$; Supplemental Figure S1c). Ethanol concentration reduced with LBB inoculation of tropical grasses and sugarcane silages $(P \leq 0.01$; Supplemental Figure S1d) and increased with temperate grasses $(P<0.01)$ and whole-plant corn silage $(P=0.07$, tendency). Inoculation increased 1,2 propanediol concentration $(P<0.05)$ in all forage types except in tropical grasses $(P=0.84)$, and the magnitude of the increase was greatest for sugarcane silage (Figure 3C).

Inoculation with LBB reduced yeast counts $(P<$ $0.05)$ in all silage types; however, the response was lower with tropical grasses $(-0.26 \mathrm{cfu} / \mathrm{g})$ and other legumes $(-0.39 \mathrm{cfu} / \mathrm{g})$ than in other forages $(-1.17$ $\mathrm{cfu} / \mathrm{g})$ and temperate grasses $(-1.19 \mathrm{cfu} / \mathrm{g})$, which had the greatest responses (Figure 3D). Inoculation with LBB also reduced mold counts $(P<0.05)$ in all silage
A

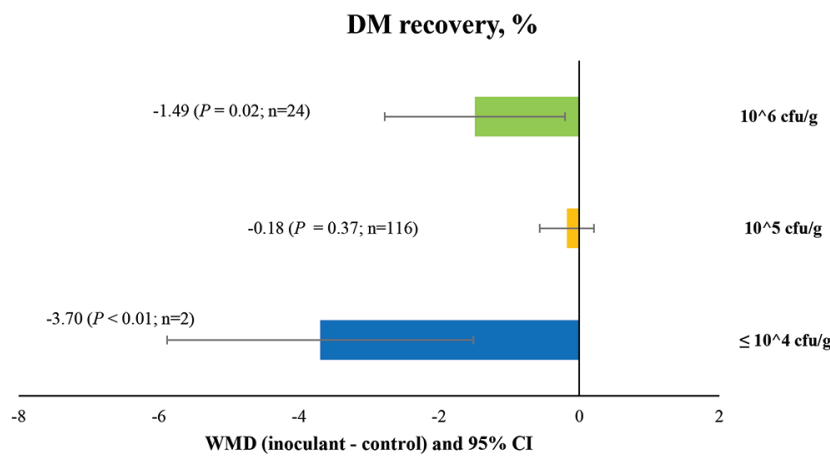

C

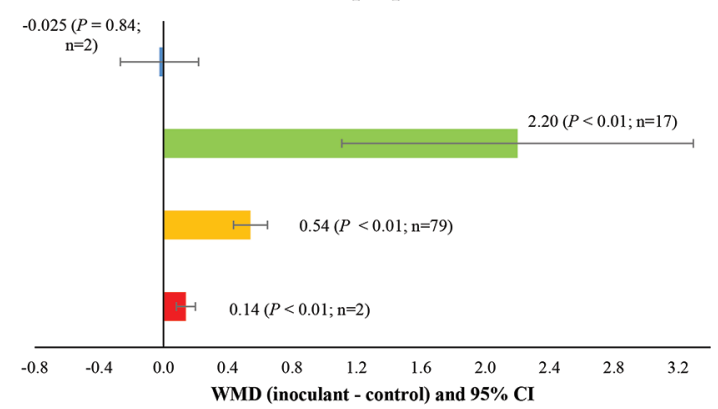

E

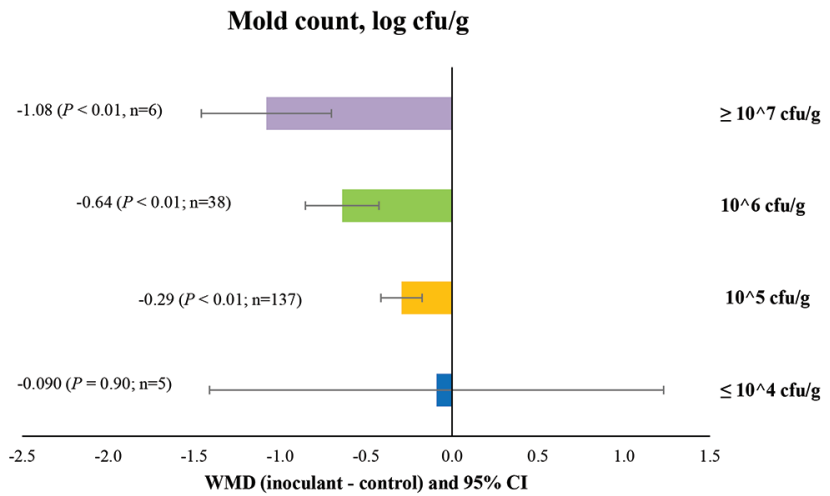

$\geq 10^{\wedge} 7 \mathrm{cfu} / \mathrm{g}$

$10^{\wedge} 6 \mathrm{cfu} / \mathrm{g}$

$10^{\wedge} 5 \mathrm{cfu} / \mathrm{g}$

$\leq 10^{\wedge} 4 \mathrm{cfu} / \mathrm{g}$
B

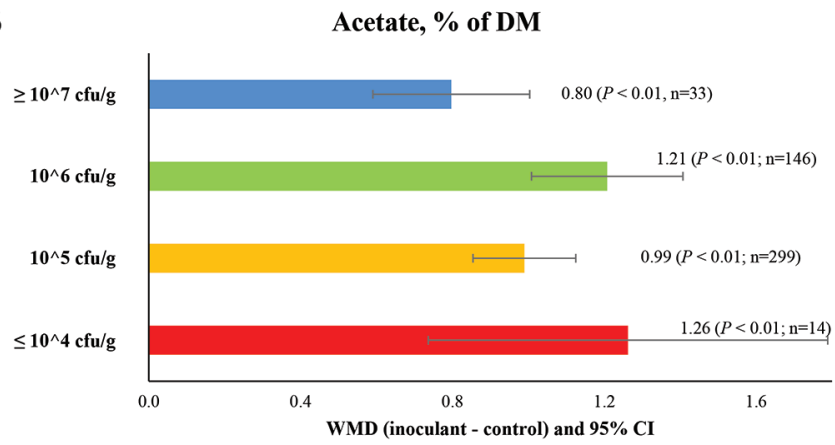

D

Yeast count, log cfu/g

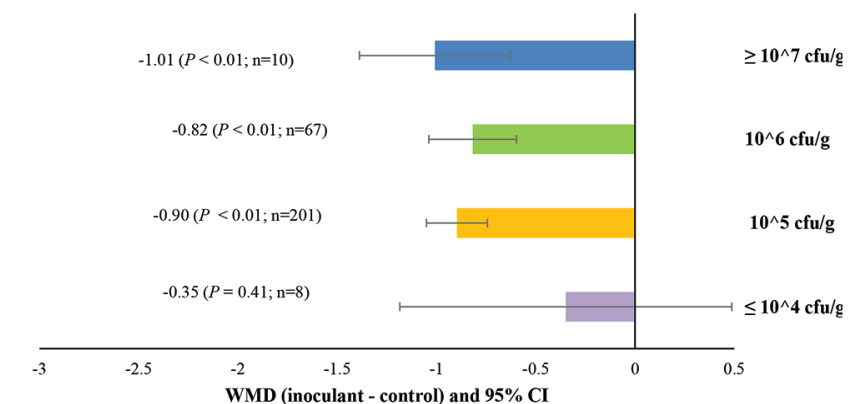

$\mathbf{F}$

Aerobic stability, h

$\geq 10^{\wedge} 7 \mathrm{cfu} / \mathrm{g}$

$10^{\wedge} 6 \mathrm{cfu} / \mathrm{g}$

$10^{\wedge} 5 \mathrm{cfu} / \mathrm{g}$

$\leq 10^{\wedge} 4 \mathrm{cfu} / \mathrm{g}$

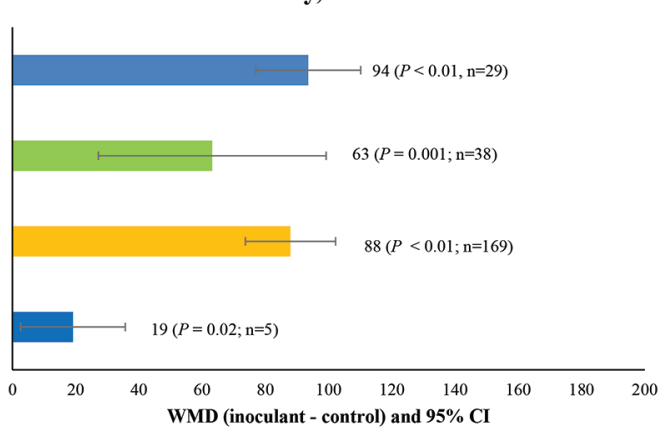

Figure 5. Inoculant application rate (subgroups A to F) effect on silage fermentation and aerobic stability responses to inoculation with Lactobacillus buchneri (LB) with or without homolactic or obligate heterolactic bacteria. WMD = weighted raw mean differences between LBinoculated and uninoculated silage. Error bars represent the confidence interval (95\%). 

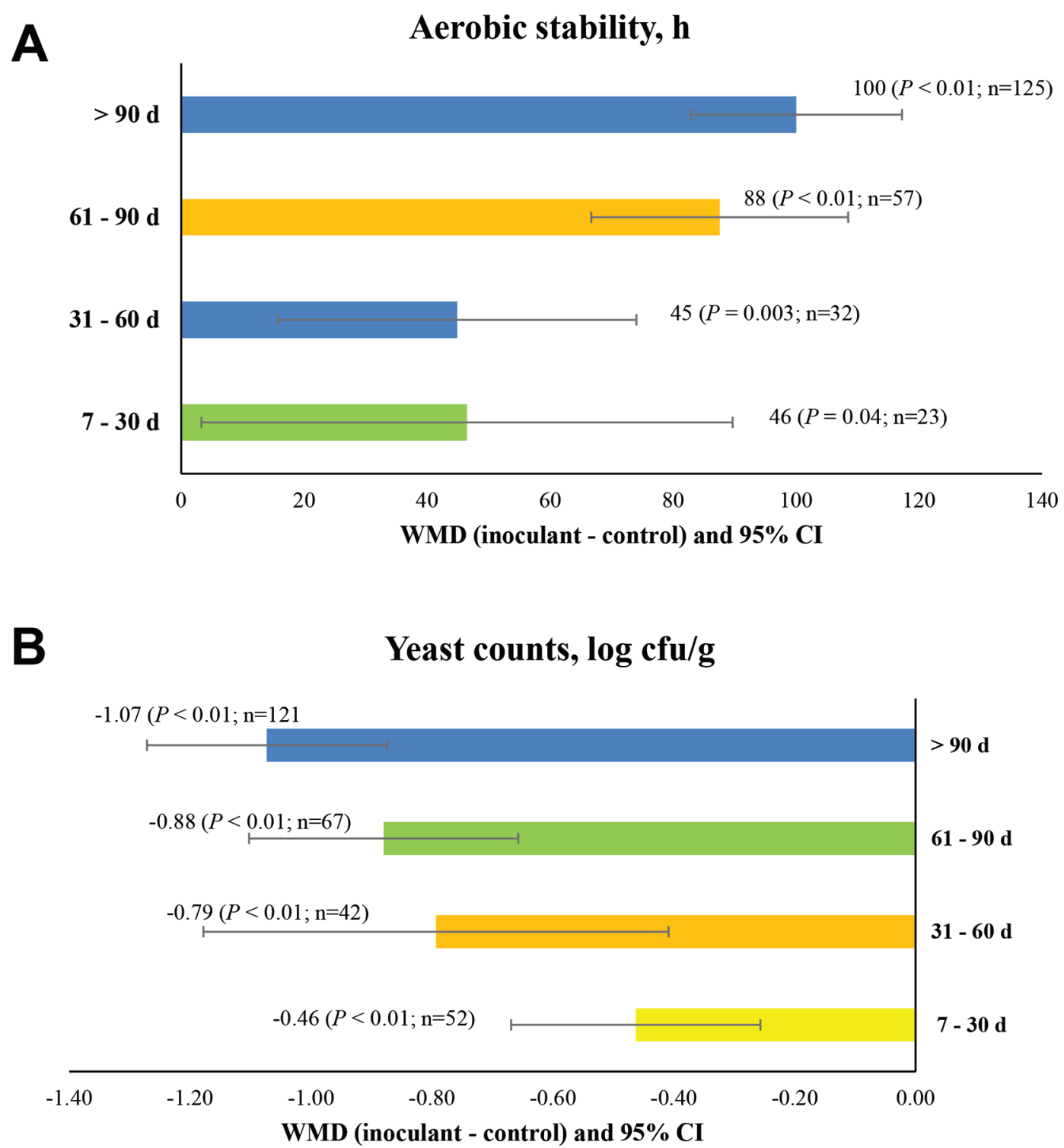

Figure 6. Effects of ensiling duration (days of ensiling) on aerobic stability and yeast responses to inoculation with Lactobacillus buchneri with or without homolactic or obligate heterolactic bacteria. WMD = weighted raw mean differences between inoculated and uninoculated silage. Error bars represent the confidence interval (95\%).

types, except in whole-plant sorghum $(P=0.60)$ and other legumes $(P=0.54$; Figure $3 \mathrm{E})$.

Inoculation with LBB increased aerobic stability $(P$ $<0.05)$ in all silage types, with the noteworthy exception of tropical grass silage $(P=0.20$; Figure $3 \mathrm{~F})$. The aerobic stability increases $(P<0.01)$ were greatest for grain silages $(199 \mathrm{~h})$ and HMC (169 h); intermediate for alfalfa $(89 \mathrm{~h})$, temperate grasses $(112 \mathrm{~h})$, wholeplant corn $(69 \mathrm{~h})$, and whole-plant sorghum silage (53 h); and lower for sugarcane (19 h) and other legumes (17 h).

\section{Effect of the LAB Species Combination on LB Inoculation Response}

Application of LB $(P<0.01)$, and $\mathrm{LB}+\mathrm{LH}(P<0.01)$ increased silage $\mathrm{pH}$ while LB+other $(P=0.07)$, and $\mathrm{LB}+\mathrm{LP}+\mathrm{EF}(P=0.09)$ tended to increase silage $\mathrm{pH}$ (Supplemental Figure S2a). Inoculation with LB+LP $(P=0.10)$ and $\mathrm{LB}+\mathrm{PP}(P=0.06)$ tended to decrease silage $\mathrm{pH}$. Dry matter recovery was decreased by LB $(P$ $<0.01)$ and increased by LB+PP $(P=0.02)$, but other inoculants had no effect $(P>0.10$; Figure $4 \mathrm{~A})$. 
Application of LB $(P<0.01)$ and $\mathrm{LB}+\mathrm{LH}(P<0.01)$ decreased lactate concentration, and only $\mathrm{LB}+\mathrm{LP}+\mathrm{PP}$ $(P<0.01)$ increased the response; $\mathrm{LB}+$ other had a similar tendency $(P=0.06$; Supplemental Figure S2b). All inoculants increased acetate concentration $(P<$ 0.01; Figure 4B); however, propionate concentrations were only increased by LB $(P<0.01)$, and $\mathrm{LB}+\mathrm{LP}+\mathrm{EF}$ $(P<0.01)$, and a tendency for improvement was observed with $\mathrm{LB}+$ other $(P=0.06$; Supplemental Figure S2c). Ethanol concentration was increased by LB $+\mathrm{LH}$ $(P=0.01), \mathrm{LB}+\mathrm{LP}+\mathrm{EF}(P=0.04)$ and $\mathrm{LB}(P=0.02)$ and decreased by LB+other $(P<0.01)$, and it tended to decrease by $\mathrm{LB}+\mathrm{LP}(P=0.07$; Supplemental Figure S2d).

Inoculation with all inoculants increased $(P<0.01)$ 1,2 propanediol concentration except $\mathrm{LB}+\mathrm{LP}+\mathrm{PP}$, which tended $(P=0.10$; Figure $4 \mathrm{C})$ to reduce the concentration but resulted in greater yeast count reductions $(P<0.01$; Figure $4 \mathrm{D})$ than LB alone $(P>0.05)$. Application of all LB inoculants reduced mold counts $(P<0.05$; except LB+LH, $P=0.11$; Figure $4 \mathrm{E})$. Inoculation with $\mathrm{LB}+\mathrm{LP}+\mathrm{PP}$ was associated with a greater aerobic stability response than $\mathrm{LB}+\mathrm{PP}, \mathrm{LB}+\mathrm{LP}+\mathrm{EF}$ or LB+other bacteria (Figure $4 \mathrm{~F}$ ).

\section{Effect of the Application Rate on LB Inoculation Response}

Inoculation rates of $10^{5}$ or $10^{6} \mathrm{cfu} / \mathrm{g}$ increased $(P<$ $0.01)$ and $\leq 10^{4}$ tended to increase $(P=0.10)$ silage $\mathrm{pH}$, whereas $\geq 10^{7} \mathrm{cfu} / \mathrm{g}$ reduced the response $(P<$ 0.01; Supplemental Figure S3a). Dry matter recovery was reduced when inoculants were applied at $\leq 10^{4}(P$ $\leq 0.01)$ and $10^{6} \mathrm{cfu} / \mathrm{g}(P=0.02)$ but not $10^{5} \mathrm{cfu} / \mathrm{g}(P$ $=0.37$; Figure $5 \mathrm{~A}$ ).

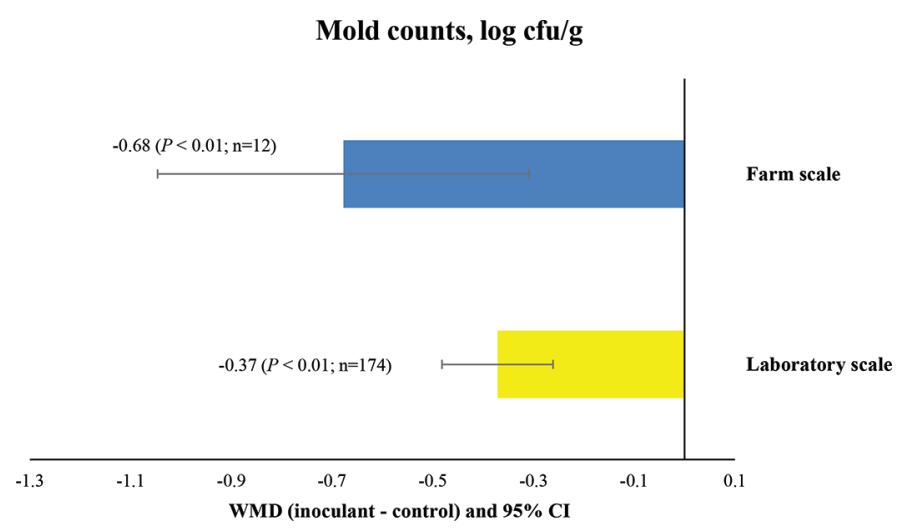

Figure 7. Effects of silo type (laboratory vs. farm scale) on mold count responses to inoculation with Lactobacillus buchneri with or without homolactic or obligate heterolactic bacteria. WMD = weighted raw mean differences between inoculated and uninoculated silage. Error bars represent the confidence interval (95\%).
Lactate concentration was increased by applying $\geq 10^{7} \mathrm{cfu} / \mathrm{g}(P<0.01)$, decreased $(P<0.01)$ by applying $10^{5}$ or $10^{6} \mathrm{cfu} / \mathrm{g}$, and unaffected by applying $\leq 10^{4}$ $\mathrm{cfu} / \mathrm{g}(P=0.52$; Supplemental Figure S3b). Acetate concentration was increased $(P<0.05)$ at all application rates (Figure 5B). Similarly, propionate concentration was increased by all application rates $(P \leq 0.02)$ except the $\leq 10^{4} \mathrm{cfu} / \mathrm{g}$ rate $(P=0.53$; Supplemental Figure S3c). Ethanol concentration was increased $(P$ $<0.01)$ by applying $10^{5}(P<0.01)$ and $\leq 10^{4} \mathrm{cfu} / \mathrm{g}$ $(P<0.01)$ and reduced by applying $\geq 10^{7} \mathrm{cfu} / \mathrm{g}(P<$ 0.01; Supplemental Figure S3d). The 1,2 propanediol concentration was increased to a greater extent by the $10^{6} \mathrm{cfu} / \mathrm{g}$ rate $(P<0.01)$ compared with $10^{5}$ and $\leq 10^{4}$ $\mathrm{cfu} / \mathrm{g}$ rates $(P<0.01)$, but unaffected $(P=0.84)$ by the $\geq 10^{7} \mathrm{cfu} / \mathrm{g}$ rate (Figure $5 \mathrm{C}$ ).

Inoculation with $10^{5}, 10^{6}$, and $\geq 10^{7} \mathrm{cfu} / \mathrm{g}$ reduced $(P$ $<0.05)$ yeast counts (Figure 5D). Mold counts were reduced $(P<0.05)$ with $10^{5}, 10^{6}$, and $\geq 10^{7} \mathrm{cfu} / \mathrm{g}$ (Figure $5 \mathrm{E})$. No effects were observed on yeast and mold counts with the $10^{4} \mathrm{cfu} / \mathrm{g}$ rate. All inoculation rates increased aerobic stability $(P<0.01)$; however, the magnitude of improvement was lower with $\leq 10^{4} \mathrm{cfu} / \mathrm{g}$ (Figure $5 \mathrm{~F}$ ).

\section{Effects of Ensiling Duration on the Inoculation Response}

The effects of ensiling duration on aerobic stability are presented in Figure 6. Ensiling for $>90 \mathrm{~d}$ resulted in greater $(P<0.01$; Figure $6 \mathrm{~A})$ improvements in aerobic stability relative to ensiling for 7 to 30 or 31 to $60 \mathrm{~d}$, which had a similar response. Similarly, greater reduction of yeast counts was observed after $90 \mathrm{~d}$ of ensiling $(P<0.01$; Figure $6 \mathrm{~B})$ relative to ensiling for 7 to $30 \mathrm{~d}$, and a similar trend was evident for the 61 to $90 \mathrm{~d}$ duration.

\section{Effects of Silo Type on the Inoculation Response}

Application of LBB reduced mold counts, regardless of the type of silo used (Figure 7), but the magnitude of reduction compared with uninoculated controls was greater (4.8-fold) for farm scale silos compared with laboratory silos (2.3-fold).

\section{Effects of Feeding Inoculated Silage on Performance of Lactating Dairy Cows}

Data from 12 peer-reviewed studies were analyzed to investigate the effects of inoculation of LBB on dairy cow performance. Six of the studies fed corn silage, whereas the rest fed other forages including wheat, sugarcane, alfalfa, and barley silage to lactating dairy 


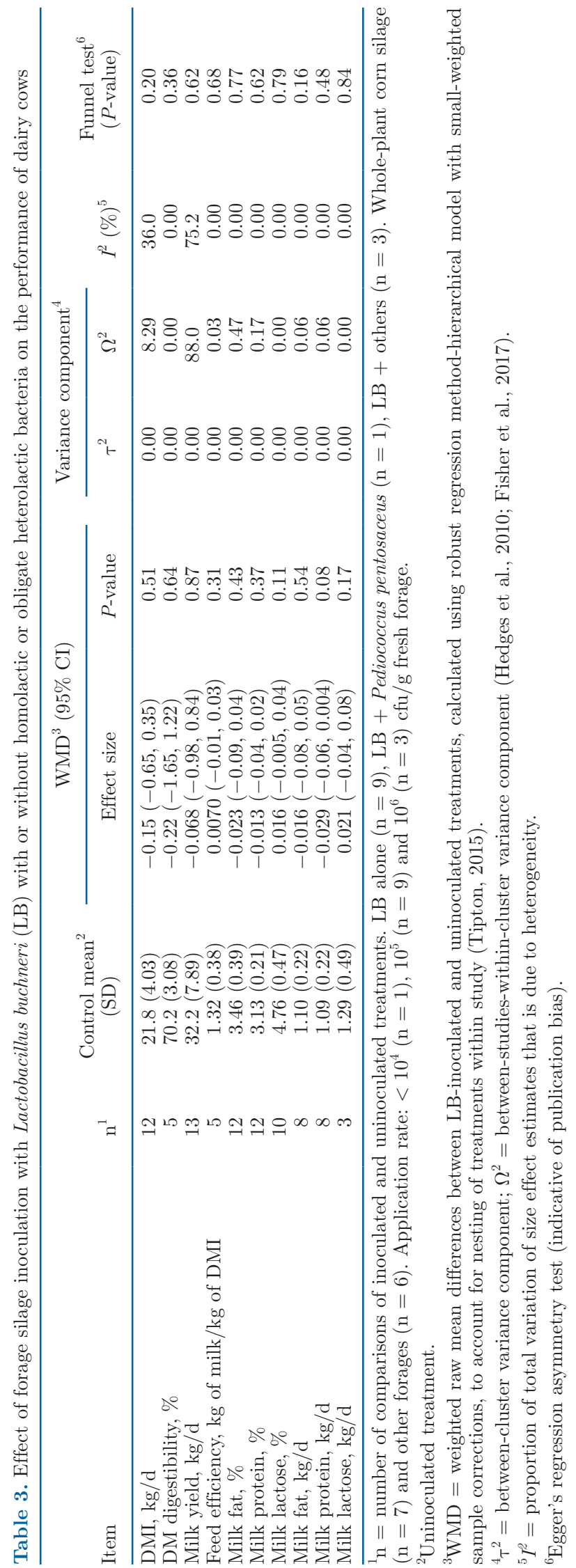

cows. The most common application rates for LBB inoculation were $10^{5}$ and $10^{6} \mathrm{cfu} / \mathrm{g}$, accounting for 66.7 and $25 \%$ of the studies, respectively. A total of $66.7 \%$ of the studies evaluated the effect of inoculation of LB alone, and the others used LB with other LAB (33.3\%).

Inoculation with LBB did not affect milk yield $(P$ $=0.87$; Table 3 ; Figure 8$)$, DMI $(P=0.51)$, feed efficiency $(P=0.31)$, DM digestibility $(P=0.64)$, milk fat $(P=0.43)$, and milk lactose $(P=0.11)$ concentration; however, it tended to reduce milk protein concentration by a small amount $(\mathrm{WMD}=-0.01 \% ; P=0.08)$. Funnel plot asymmetry was not observed $(P>0.10)$ for any performance variable, indicating that publication bias was not evident.

Heterogeneity was high for milk yield $\left(I^{2}=75.2\right)$ and low for DMI $\left(I^{2}=36.0\right.$; Table 3$)$. Based on the subgroup analysis of milk yield responses, which should be cautiously interpreted due to the few studies involved, feeding LBB-inoculated whole-plant corn as the basal forage tended to reduce milk yield $(P=0.09)$ but no effects were observed with feeding other inoculated forages $(P=0.21$; Supplemental Figure S4a, https:// doi.org/10.7910/DVN/ANYKJ5). Similarly, no effects were observed on milk yield when cows were fed silage inoculated with LB alone $(P=0.16)$; however, feeding forages inoculated with LBB reduced milk yield $(P$ $<0.01$; Supplemental Figure S4b; $\mathrm{n}=3$ ). Application rate did not affect the milk yield response $(P>0.10$; Supplemental Figure S4c). Basal forage type, inoculant LAB composition and inoculation rate did not affect DMI (data not shown).

\section{DISCUSSION}

\section{Silage Quality and Stability}

Across forage types, LBB inoculation decreased lactate concentration; increased $\mathrm{pH}, \mathrm{DM}$ losses, and concentrations of acetate, 1,2 propanediol and propionate; decreased yeast and mold counts; and increased aerobic stability. Silages inoculated with LB typically contain less lactate and more acetate than untreated silages because the bacterium converts lactate to acetate and 1,2-propanediol during silage fermentation (Oude Elferink et al., 2001). The 1,2 propanediol can be converted into propionate by $L$. diolivorans (Krooneman et al., 2002), L. reuteri (Sriramulu et al., 2008) and by a novel strain of L. buchneri A KKP 2047p in the presence of cobalamine (Zielińska et al., 2017). Due to their antifungal nature, the greater acetate and propionate concentrations of LB-inoculated silages inhibit spoilage yeast and molds (Moon, 1983), resulting in improved aerobic stability (Oude Elferink et al., 2001; Pahlow et al., 2003). Additionally, LB may also produce other 
Forest Plot

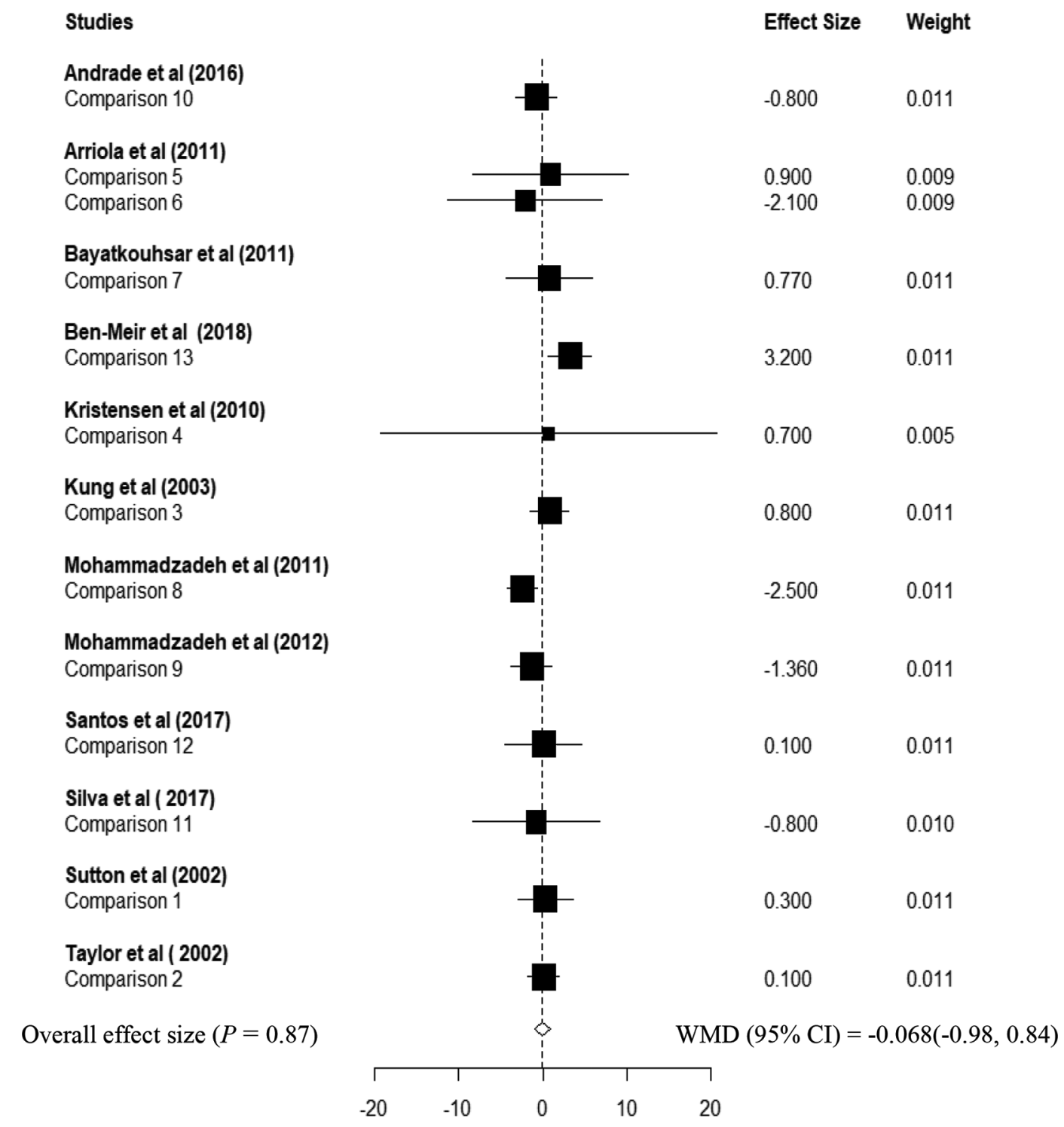

Figure 8. Forest plot showing the effects of forage inoculation with Lactobacillus buchneri with or without homolactic or obligate heterolactic bacteria on milk yield $(\mathrm{kg} / \mathrm{d})$ by dairy cows. The $\mathrm{x}$-axis shows the WMD; squares to the left of the line represent reduction, whereas squares to the right of the line indicate an increase in milk yield $(\mathrm{kg} / \mathrm{d})$. Each square represents the mean size effect for that study, and the size of the squares reflects the relative weighting of the study to the overall size effect estimate, with larger squares representing greater weight. The lines connected to the squares represent the upper and lower $95 \%$ confidence interval for the size effect. The dotted vertical line represents the overall size effect estimate. The diamond at the bottom represents the mean response across the studies. WMD = weighted raw mean differences between LB-inoculated and uninoculated treatments. (Sutton et al., 2002; Bayatkouhsar et al., 2011; Mohammadzadeh et al., 2011, 2012; Andrade et al., 2016; Santos et al., 2017).

antimicrobial substances, such as buchnericin, a bacteriocin that may contribute to increased aerobic stability (Yildirim, 2001).

The meta-analysis of Kleinschmit and Kung (2006) reported greater aerobic stability in LB-treated corn silage $\left(>10^{5} \mathrm{cfu} / \mathrm{g}\right)$, grass, and small grain silages $\left(\leq 10^{5}\right.$ and $\left.>10^{5} \mathrm{cfu} / \mathrm{g}\right)$ than in untreated silages. The results of the current meta-analysis support the latter by showing that inoculation with LBB improved aerobic stability in all forages examined except tropical grasses which were not specifically examined in the previous meta-analysis. The increased aerobic stability in most forages in the current study is largely because LB increased acetate concentration at the expense of lactate concentration, reduced yeast counts in all forages, and reduced mold counts in most forages. 
The lack of an aerobic stability response for tropical grasses may be due to the relatively low number of observations $(\mathrm{n}=6)$, wide variation in responses and in particular the insufficient levels of lactate substrate for LB to convert to acetate and propionate (via 1,2 propanediol), which are the main antifungal compounds in silage. The high variability in responses for tropical grasses partly reflects wide morphological and chemical differences in tropical forages (bermudagrass vs. elephant grass vs. guinea grass), which may have contributed to differences in porosity and density after packing.

Aerobic stability was increased by the different LBB inoculants in this study as in others (Blajman et al., 2018; Zhang et al., 2018; Bernardi et al., 2019). For unknown reasons, the magnitude of improvement in aerobic stability was greater when $\mathrm{LB}+\mathrm{LP}+\mathrm{PP}$ was applied instead of other bacterial combinations, except $\mathrm{LB}$ alone and $\mathrm{LB}+\mathrm{LP}$. Interestingly, the response of LB alone did not differ from those of combinations of LB and other LAB. This is because, for most of such combinations, LB was the main bacteria contributing to aerobic stability, as the other LAB were added to improve the fermentation and DM recovery. The exception could be LH, which similarly to LB is also an obligate heterolactic bacterium added to improve aerobic stability earlier than LB (Ferrero et al., 2019a; Arriola et al., 2021). The metabolic pathway for converting lactate into acetate and 1,2 propanediol is common for both LH and LB (Heinl et al., 2012); hence, previous studies have shown the efficacy of LH at improving aerobic stability in sugar cane (Avila et al., 2012, Carvalho et al., 2015), whole-plant corn silage (Reis et al., 2018, Ferrero et al., 2019b) and whole-plant sorghum silage (Ferrero et al., 2019a; Arriola et al., 2021).

Schmidt et al. (2009) suggested that LB inoculants need at least $45 \mathrm{~d}$ to improve aerobic stability. This is supported by this study because the magnitude of improvement in aerobic stability was greater after $90 \mathrm{~d}$ of ensiling, and a similar trend was evident after 61 to 90 $\mathrm{d}$ versus shorter ensiling durations. Nevertheless, it is noteworthy that, though less pronounced, aerobic stability increases were evident after 7 to $30 \mathrm{~d}$ of ensiling. This is one of the reasons why LH has been examined as an alternative to LB, but the results of early studies are inconclusive for forages (Ferrero et al., 2019a; Nair et al., 2020; Arriola et al., 2021) but promising for HMC (da Silva et al., 2020).

Early concerns that the heterolactic nature of LB would cause large losses of DM from silages were not substantiated by the meta-analyses of Kleinschmit and Kung (2006), who reported DM losses of 1 (corn silages) to $1.8 \%$ (grass and small grain silages) with LB inoculation. In the current meta-analysis, inoculation with
LBB only decreased DM recovery of whole-plant corn silage by a small amount $(-0.78 \%)$ but increased or did not affect those of others. Applying LB alone reduced DM recovery (by $0.7 \%$ ) but no reduction was evident when other bacteria were applied with $\mathrm{LB}$ or when it was applied at the recommended $10^{5} \mathrm{cfu} / \mathrm{g}$ dose. The current meta-analysis therefore supports the notion that losses of DM due to heterofermentation by LBB inoculants are generally small and are forage, inoculant composition, and dose specific (Kleinschmit and Kung, 2006). In addition, adding complementary LAB such as $\mathrm{LP}, \mathrm{PP}$, and $\mathrm{LP}+\mathrm{PP}$, to $\mathrm{LB}$ prevented the increase in $\mathrm{pH}$ and or decrease in DM recovery that resulted from applying obligate heterolactic LB or LB+LH. Therefore, addition of homolactic or facultative heterolactic LAB to LB increased acidification in some cases and prevented the small losses in DM that occurred when LB alone was applied. The meta-analysis of Bernardi et al. (2019) also showed that applying inoculants that combine heterolactic bacteria with obligate homolactic or facultative heterolactic bacteria improved silage fermentation, reduced yeast and mold counts and therefore improved aerobic stability. However, unlike in the current study, Bernardi et al. (2019) showed that homolactic and obligate heterolactic bacteria increased DM losses. This difference may reflect the inclusion of older studies (1980 to 2017), as well as those published in Portuguese and Spanish in that study.

The recommended dose for LAB inoculants in parts of Asia and South America is $\leq 10^{4} \mathrm{cfu} / \mathrm{g}$; however, it is typical to use $10^{5} \mathrm{cfu} / \mathrm{g}$ in the United States and $10^{6}$ $\mathrm{cfu} / \mathrm{g}$ in Europe (Oliveira et al., 2017). All inoculation rates, except $\leq 10^{4} \mathrm{cfu} / \mathrm{g}$, reduced yeast counts. Accordingly, aerobic stability was greater at higher doses than at the $\leq 10^{4} \mathrm{cfu} / \mathrm{g}$ dose. This was probably because the $\leq 10^{4} \mathrm{cfu} / \mathrm{g}$ rate had insufficient bacteria to dominate the epiphytic population.

The considerable increase in lactate concentration, relatively small increase in acetate, and lack of a 1,2 propanediol response at the $\geq 10^{7} \mathrm{cfu} / \mathrm{g}$ rate, suggests that the classical fermentation of lactate into 1,2 propanediol and acetate by LB was curtailed at this high dose. However, the result should be cautiously interpreted because only a few studies used this high rate ( $\mathrm{n}=2$ for such studies that measured 1,2 propanediol). Why the high dose would curtail the typical LB response is unclear, but it may be related to $\mathrm{pH}$ effects on lactic acid degradation by LB. This high dose is typically too expensive for routine use on farms, and it did not improve DM recovery, acetate concentration, yeast and mold counts, or aerobic stability relative to the $10^{5}$ or $10^{6} \mathrm{cfu} / \mathrm{g}$ rates. Therefore, the $10^{5}$ or $10^{6} \mathrm{cfu} / \mathrm{g}$ were the best application rates for improving silage preservation in this study. 


\section{Performance of Dairy Cows}

The effects of feeding silage treated with $\mathrm{LB}$ on performance of dairy cows in the literature have been inconsistent. Although some studies have observed a greater milk yield response (Kung et al., 2003), others did not (Taylor et al., 2002; Arriola et al., 2011b; da Silva et al., 2017). Kleinschmit and Kung (2006) questioned whether the high acetate concentrations of LBinoculated forages would reduce DMI. However, studies conducted to date have found no adverse effect on DMI when LB-inoculated silage was fed to dairy cows (Taylor et al., 2002; Kung et al., 2003; Arriola et al., 2011b). In the present study, no effects of feeding LBB-inoculated silage on DMI, milk yield, DM digestibility, feed efficiency, and milk fat percent were detected. However, inoculation of silage was associated with a small $(-0.6$ percentage units) reduction in milk protein concentration, which is unclear because inoculation with $\mathrm{LAB}$ generally improves ruminal function by stimulating rumen microbes, increasing VFA production (Weinberg et al., 2003), increasing NDF degradability (Weinberg et al., 2007) or increasing microbial protein synthesis (Contreras-Govea et al., 2011).

Bernardi et al. (2019) showed that applying heterolactic LAB alone to corn silage did not affect milk yield by dairy cows but applying LBB reduced milk yield. This study differed in scope from the current study as they included studies that were older, that involved different bacteria and were published in Portuguese and Spanish. Reasons for trends in this study for LBB inoculation of corn but not for other forages or for LBB but not LB inoculation to reduce milk yield are not clear. The latter milk yield responses should be cautiously interpreted because few studies were involved; the tendencies observed suggest that statistical power may have been insufficient. More research is needed on the effects of LBB inoculants on the performance of dairy cows.

\section{CONCLUSIONS}

Silage inoculation with LBB increased aerobic stability due to greater acetate concentration and lower yeast counts for all inoculant combinations, rates of inoculation, and forage types except tropical forages. Aerobic stability was improved by LBB inoculation at all ensiling durations examined but was greater with $>90 \mathrm{~d}$ of ensiling. The DM losses with LBB inoculation were generally small and were forage, inoculant composition, and dose specific. Adding other bacteria to LB prevented the small loss in DM caused by LB alone. The best application rates for preventing DM losses, increasing acetate concentrations, reducing yeast counts and increasing aerobic stability were $10^{5}$ and $10^{6}$ $\mathrm{cfu} / \mathrm{g}$ fresh forage. Feeding LBB-inoculated silage had no effects on DMI, DM digestibility, and feed efficiency.

\section{ACKNOWLEDGMENTS}

The authors have not stated any conflicts of interest.

\section{REFERENCES}

Andrade, F. L., J. P. P. Rodrigues, E. Detmann, S. C. Valadares Filho, M. M. D. Castro, A. S. Trece, T. E. Silva, V. Fischer, K. Weiss, and M. I. Marcondes. 2016. Nutritional and productive performance of dairy cows fed corn silage or sugarcane silage with or without additives. Chil. J. Agric. Res. 48:747-753. https://doi .org/10.1007/s11250-016-1020-y.

Arriola, K. G., S. C. Kim, and A. T. Adesogan. 2011a. Effect of applying inoculants with heterolactic or homolactic and heterolactic bacteria on the fermentation and quality of corn silage. J. Dairy Sci. 94:1511-1516. https://doi.org/10.3168/jds.2010-3807.

Arriola, K. G., S. C. Kim, C. R. Staples, and A. T. Adesogan. 2011b. Effect of applying bacterial inoculants containing different types of bacteria to corn silage on the performance of dairy cattle. J. Dairy Sci. 94:3973-3979. https://doi.org/10.3168/jds.2010-4070.

Arriola, K. G., O. C. M. Queiroz, J. J. Romero, D. Casper, E. Muniz, J. Hamie, and A. T. Adesogan. 2015. Effect of microbial inoculants on the quality and aerobic stability of bermudagrass roundbale haylage. J. Dairy Sci. 98:478-485. https://doi.org/10.3168/ jds.2014-8411.

Arriola, K. G., D. Vyas, D. Kim, M. C. Agarussi, V. P. Silva, J. M. Flores, Y. Jiang, X. Yanlin, A. A. Pech-Cervantes, L. F. Ferraretto, and A. T. Adesogan. 2021. Effect of Lactobacillus hilgardii, Lactobacillus buchneri or their combination on the fermentation and nutritive value of sorghum silage and corn silage. J. Dairy Sci. 104. https://doi.org/10.3168/jds.2020-19512.

Ávila, C. L. D., J. C. Pinto, D. P. Oliveira, and R. F. Schwan. 2012. Aerobic stability of sugar cane silages with a novel strain of Lactobacillus sp isolated from sugar cane. Rev. Bras. Zootec. 41:249-255. https://doi.org/10.1590/S1516-35982012000200003.

Bayatkouhsar, J., A. M. Tahmasebi, and A. A. Naserian. 2011. The effects of microbial inoculation of corn silage on performance of lactating dairy cows. Livest. Sci. 142:170-174. https://doi.org/10 .1016/j.livsci.2011.07.007.

Ben-Meir, Y. A., E. Jami, Y. Portnik, S. Ya'acoby, Y. Chen, I. M. Ogunade, A. T. Adesogan, and Z. G. Weinberg. 2018. Effect of silage inoculants on the quality of baled whole-crop wheat silages and milking cow performance. Grassl. Sci. 64:207-214. https://doi .org/10.1111/grs.12196.

Bernardi, A., C. J. Härter, A. W. L. Silva, R. A. Reis, and C. H. S. Rabelo. 2019. A meta-analysis examining lactic acid bacteria inoculants for maize silage: Effects on fermentation, aerobic stability, nutritive value and livestock production. Grass Forage Sci. 74:596-612. https://doi.org/10.1111/gfs.12452.

Blajman, J. E., R. B. Páez, C. G. Vinderola, M. S. Lingua, and M. L. Signorini. 2018. A meta-analysis on the effectiveness of homofermentative and heterofermentative lactic acid bacteria for corn silage. J. Appl. Microbiol. 125:1655-1669. https://doi.org/10.1111/ jam.14084.

Borenstein, M., J. P. T. Higgins, L. V. Hedges, and H. R. Rothstein. 2017. Basics of meta-analysis: $I^{2}$ is not an absolute measure of heterogeneity. Res. Synth. Methods 8:5-18. https://doi.org/10.1002/ jrsm. 1230 .

Buchanan-Smith, J. G. 1990. An investigation into palatability as a factor responsible for reduced intake of silage by sheep. Anim. Prod. 50:253-260. https://doi.org/10.1017/S0003356100004700.

Carvalho, B. F., C. L. S. Ávila, M. G. C. P. Miguel, J. C. Pinto, M. C. Santos, and R. F. Schwan. 2015. Aerobic stability of sugar-cane 
silage inoculated with tropical strains of lactic acid bacteria. Grass Forage Sci. 70:308-323. https://doi.org/10.1111/gfs.12117.

Contreras-Govea, F. E., R. E. Muck, D. R. Mertens, and P. J. Weimer. 2011. Microbial inoculant effects on silage and in vitro ruminal fermentation, and microbial biomass estimation for alfalfa, bmr corn, and corn silages. Anim. Feed Sci. Technol. 163:2-10. https:/ /doi.org/10.1016/j.anifeedsci.2010.09.015.

Cook, R. D. 1977. Detection of influential observation in linear regression. Technometrics 19:15-18. https://doi.org/10.1080/00401706 .1977.10489493.

da Silva, J., J. P. P. Winckler, M. H. O. Pasetti, P. A. R. Salvo, N. B. Kristensen, J. L. P. Daniel, and L. G. Nussio. 2017. Effects of Lactobacillus buchneri inoculation or 1-propanol supplementation to corn silage on the performance of lactating Holstein cows. Rev. Bras. Zootec. 46:591-598. https://doi.org/10.1590/s1806 -92902017000700006.

da Silva, E. B., M. L. Smith, R. M. Savage, S. A. Polukis, P. Drouin, and L. Kung Jr.. 2020. Effects of Lactobacillus hilgardii 4785 and Lactobacillus buchneri 40788 on the bacterial community, fermentation, and aerobic stability of high-moisture corn silage. J. Appl. Microbiol. https://doi.org/10.1111/jam.14892.

Driehuis, F., S. J. W. H. Oude Elferink, and S. F. Spoelstra. 1999. Anaerobic lactic acid degradation during ensilage of whole crop maize inoculated with Lactobacillus buchneri inhibits yeast growth and improves aerobic stability. J. Appl. Microbiol. 87:583-594. https:/ /doi.org/10.1046/j.1365-2672.1999.00856.x.

Driehuis, F., S. W. H. Oude Elferink, and P. G. Van Wikselaar. 2001. Fermentation characteristics and aerobic stability of grass silage inoculated with Lactobacillus buchneri, with or without homofermentative lactic acid bacteria. Grass Forage Sci. 56:330-343. https: //doi.org/10.1046/j.1365-2494.2001.00282.x.

Egger, M., G. D. Smith, M. Schneider, and C. Minder. 1997. Bias in meta-analysis detected by a simple, graphical test. BMJ 315:629634. https://doi.org/10.1136/bmj.315.7109.629.

Ferrero, F., S. Piano, E. Tabacco, and G. Borreani. 2019a. Effects of conservation period and Lactobacillus hilgardii inoculum on the fermentation profile and aerobic stability of whole corn and sorghum silages. J. Sci. Food Agric. 99:2530-2540. https://doi.org/10 $.1002 /$ jsfa.9463.

Ferrero, F., S. Prencipe, D. Spadaro, M. L. Gullino, L. Cavallarin, S. Piano, E. Tabacco, and G. Borreani. 2019b. Increase in aflatoxins due to Aspergillus section Flavi multiplication during the aerobic deterioration of corn silage treated with different bacteria inocula. J. Dairy Sci. 102:1176-1193. https://doi.org/10.3168/jds .2018-15468.

Fisher, Z., E. Tipton, and H. Zhipeng. 2017. Package "robumeta." https://cran.r-project.org/web/packages/robumeta/robumeta .pdf.

Gherardi, S. G., and J. L. Black. 1991. Effect of palatability on voluntary feed-intake by sheep. 1. Identification of chemicals that alter the palatability of a forage. Aust. J. Agric. Res. 42:571-584. https: //doi.org/10.1071/AR9910571.

Hedges, L. V., E. Tipton, and M. C. Johnson. 2010. Robust variance estimation in meta-regression with dependent effect size estimates. Res. Synth. Methods 1:39-65. https://doi.org/10.1002/jrsm.5.

Heinl, S., D. Wibberg, F. Eikmeyer, R. Szczepanowski, J. Blom, B. Linke, A. Goesmann, R. Grabherr, H. Schwab, A. Puhler, and A. Schluter. 2012. Insights into the completely annotated genome of Lactobacillus buchneri CD034, a strain isolated from stable grass silage. J. Biotechnol. 161:153-166. https://doi.org/10.1016/ j.jbiotec.2012.03.007.

Higgins, J. P. T., S. G. Thompson, J. J. Deeks, and D. G. Altman. 2003. Measuring inconsistency in meta-analyses. BMJ 327:557560. https://doi.org/10.1136/bmj.327.7414.557.

Jatkauskas, J., and V. Vrotniakiene. 2011. The effects of silage inoculants on the fermentation and aerobic stability of legume-grass silage. Žemdirbystè (Agriculture) 98:367-374.

Kleinschmit, D. H., and L. Kung Jr.. 2006. A meta-analysis of the effects of Lactobacillus buchneri on the fermentation and aerobic stability of corn and grass and small-grain silages. J. Dairy Sci.
89:4005-4013. https://doi.org/10.3168/jds.S0022-0302(06)72444 -4 .

Kristensen, N. B., K. H. Sloth, O. Højberg, N. H. Spliid, C. Jensen, and R. Thøgersen. 2010. Effects of microbial inoculants on corn silage fermentation, microbial contents, aerobic stability, and milk production under field conditions. J. Dairy Sci. 93:3764-3774. https://doi.org/10.3168/jds.2010-3136.

Krooneman, J., F. Faber, A. C. Alderkamp, S. J. H. W. Oude Elferink, F. Driehuis, I. Cleenwerck, J. Swings, J. Gottschal, and M. Vancanneyt. 2002. Lactobacillus diolivorans sp. nov., a 1,2-propanediol-degrading bacterium isolated from aerobically stable maize silage. Int. J. Syst. Evol. Microbiol. 52:639-646. https://doi.org/ 10.1099/00207713-52-2-639.

Kung, L. 1998. A review on silage additives and enzymes. Pages $121-$ 135 in Proc. Proceedings of the 59th Minneapolis Nutrition Conference, Minneapolis, MN. Department of Animal Science, University of Minnesota, St. Paul.

Kung, L. Jr., C. C. Taylor, M. P. Lynch, and J. M. Neylon. 2003. The effect of treating alfalfa with Lactobacillus buchneri 40788 on silage fermentation, aerobic stability, and nutritive value for lactating dairy cows. J. Dairy Sci. 86:336-343. https://doi.org/10.3168/jds .S0022-0302(03)73611-X.

Lean, I. J., M. B. de Ondarza, C. J. Sniffen, J. E. P. Santos, and K. E. Griswold. 2018. Meta-analysis to predict the effects of metabolizable amino acids on dairy cattle performance. J. Dairy Sci. 101:340-364. https://doi.org/10.3168/jds.2016-12493.

Light, R. J., and D. B. Pillemer. 1984. Summing up: The science of reviewing research. Harvard University Press.

Littell, R. C., P. R. Henry, and C. B. Ammerman. 1998. Statistical analysis of repeated measures data using SAS procedures. J. Anim. Sci. 76:1216-1231. https://doi.org/10.2527/1998.7641216x.

Mari, L. J., R. J. Schmidt, L. G. Nussio, C. M. Hallada, and L. Kung Jr.. 2009. An evaluation of the effectiveness of Lactobacillus buchneri 40788 to alter fermentation and improve the aerobic stability of corn silage in farm silos. J. Dairy Sci. 92:1174-1176. https://doi .org/10.3168/jds.2008-1700.

Mohammadzadeh, H., M. Khorvash, G. R. Ghorbani, and W. Z. Yang. 2011. Effects of a dual-purpose bacterial inoculant on the fermentation characteristics of high-moisture maize silage and dairy cattle performance. S. Afr. J. Anim. Sci. 41:368-376. https://doi.org/ 10.4314/sajas.v41i4.7.

Mohammadzadeh, H., M. Khorvash, G. R. Ghorbani, and W. Z. Yang. 2012. Frosted corn silage with or without bacterial inoculants in dairy cattle ration. Livest. Sci. 145:153-159. https://doi.org/10 $.1016 /$ j.livsci.2012.01.011.

Moher, D., A. Liberati, J. Tetzlaff, D. G. Altman, The PRISMA Group. 2009. Preferred reporting items for systematic reviews and meta-analyses: The PRISMA statement. https://doi.org/10.1371/ journal.pmed.1000097.

Moon, N. J. 1983. Inhibition of the growth of acid tolerant yeasts by acetate, lactate and propionate and their synergistic mixtures. J. Appl. Bacteriol. 55:453-460. https://doi.org/10.1111/j.1365-2672 .1983.tb01685.x.

Muck, R. E. 1996. A lactic acid bacterial strain to improve aerobic stability of silages. Pages $42-43$ in U.S. Dairy Forage Res. Center 1996 Res. Summaries. US Department of Agriculture, Agricultural Research Service.

Muck, R. E., E. M. G. Nadeau, T. A. McAllister, F. E. ContrerasGovea, M. C. Santos, and L. Kung Jr.. 2018. Silage review: Recent advances and future uses of silage additives. J. Dairy Sci. 101:3980-4000. https://doi.org/10.3168/jds.2017-13839.

Nair, J., N. Huaxin, E. Andrada, H. E. Yang, E. Chevaux, P. Drouin, T. A. McAllister, and Y. Wang. 2020. Effects of inoculation of corn silage with Lactobacillus hilgardii and Lactobacillus buchneri on silage quality, aerobic stability, nutrient digestibility, and growth performance of growing beef cattle. J. Anim. Sci. 98:skaa267. https://doi.org/10.1093/jas/skaa267.

Oliveira, A. S., Z. G. Weinberg, I. M. Ogunade, A. A. P. Cervantes, K. G. Arriola, Y. Jiang, D. Kim, X. Li, M. C. M. Gonçalves, D. Vyas, and A. T. Adesogan. 2017. Meta-analysis of effects of inoculation 
with homofermentative and facultative heterofermentative lactic acid bacteria on silage fermentation, aerobic stability, and the performance of dairy cows. J. Dairy Sci. 100:4587-4603. https://doi .org/10.3168/jds.2016-11815.

Oude Elferink, S. J., J. Krooneman, J. C. Gottschal, S. F. Spoelstra, F. Faber, and F. Driehuis. 2001. Anaerobic conversion of lactic acid to acetic acid and 1,2-propanediol by Lactobacillus buchneri. Appl. Environ. Microbiol. 67:125-132. https://doi.org/10.1128/ AEM.67.1.125-132.2001.

Pahlow, G., R. E. Muck, F. Driehuis, S. J. W. H. Oude Elferink, and S. F. Spoelstra. 2003. Microbiology of ensiling. Pages 31-93 in Silage Science and Technology. D. R. Buxton, R. E. Muck, J. H. Harrison, ed. American Society of Agronomy, Crop Science Society of America, Soil Science Society of America. https://doi.org/10 .2134/agronmonogr42.c2.

Ranjit, N. K., and L. Kung Jr.. 2000. The effect of Lactobacillus buchneri, Lactobacillus plantarum, or a chemical preservative on the fermentation and aerobic stability of corn silage. J. Dairy Sci. 83:526-535. https://doi.org/10.3168/jds.S0022-0302(00)74912-5.

Reis, C. B., A. de Oliveira dos Santos, B. F. Carvalho, R. F. Schwan, and C. L. D. Ávila. 2018. Wild Lactobacillus hilgardii (CCMA 0170) strain modifies the fermentation profile and aerobic stability of corn silage. J. Appl. Anim. Res. 46:632-638. https://doi.org/10 $.1080 / 09712119.2017 .1371609$

Roman-Garcia, Y., R. R. White, and J. L. Firkins. 2016. Meta-analysis of postruminal microbial nitrogen flows in dairy cattle. I. Derivarion of equations. J. Dairy Sci. 99:7918-7931. https://doi.org/10 $.3168 /$ jds.2015-10661.

Santos, W. P., C. L. S. Ávila, M. N. Pereira, R. F. Schwan, N. M. Lopes, and J. C. Pinto. 2017. Effect of the inoculation of sugarcane silage with Lactobacillus hilgardii and Lactobacillus buchneri on feeding behavior and milk yield of dairy cows. J. Anim. Sci. 95:4613-4622. https://doi.org/10.2527/jas2017.1526.

Schmidt, R. J., W. Hu, J. A. Mills, and L. Kung Jr.. 2009. The development of lactic acid bacteria and Lactobacillus buchneri and their effects on the fermentation of alfalfa silage. J. Dairy Sci. 92:5005-5010. https://doi.org/10.3168/jds.2008-1701.

Sriramulu, D. D., M. Liang, D. Hernandez-Romero, E. Raux-Deery, H. Lünsdorf, J. B. Parsons, M. J. Warren, and M. B. Prentice. 2008. Lactobacillus reuteri DSM 20016 produces cobalamin-dependent diol dehydratase in metabolosomes and metabolizes 1, 2-propanediol by disproportionation. J. Bacteriol. 190:4559-4567. https:// doi.org/10.1128/JB.01535-07.

Sutton, J. D., R. H. Phipps, E. R. Deaville, A. K. Jones, and D. J. Humphries. 2002. Whole-crop wheat for dairy cows: Effects of crop maturity, a silage inoculant and an enzyme added before feeding on food intake and digestibility and milk production. Anim. Sci. 74:307-318. https://doi.org/10.1017/S1357729800052474.

Tabacco, E., S. Piano, A. Revello-Chion, and G. Borreani. 2011. Effect of Lactobacillus buchneri LN4637 and Lactobacillus buchneri LN40177 on the aerobic stability, fermentation products, and microbial populations of corn silage under farm conditions. J. Dairy Sci. 94:5589-5598. https://doi.org/10.3168/jds.2011-4286.

Taylor, C. C., N. J. Ranjit, J. A. Mills, J. M. Neylon, and L. Kung Jr.. 2002. The effect of treating whole-plant barley with Lactobacillus buchneri 40788 on silage fermentation, aerobic stability, and nutritive value for dairy cows. J. Dairy Sci. 85:1793-1800. https://doi .org/10.3168/jds.S0022-0302(02)74253-7.

Tipton, E. 2015. Small sample adjustments for robust variance estimation with meta-regression. Psychol. Methods 20:375-393. https:// doi.org/10.1037/met0000011.
Vesterinen, H. M., E. S. Sena, K. J. Egan, T. C. Hirst, L. Churolov, G. L. Currie, A. Antonic, D. W. Howells, and M. R. Macleod. 2014. Meta-analysis of data from animal studies: A practical guide. J. Neurosci. Methods 221:92-102. https://doi.org/10.1016/ j.jneumeth.2015.11.021.

Viechtbauer, W. 2010. Conducting Meta-Analyses in R with the metafor Package. J. Stat. Softw. 36:1-48. https://doi.org/10.18637/jss .v036.i03.

Weinberg, Z., G. Szakacs, G. Ashbell, and Y. Hen. 1999. The effect of Lactobacillus buchneri and L. plantarum, applied at ensiling, on the ensiling fermentation and aerobic stability of wheat and sorghum silages. J. Ind. Microbiol. Biotechnol. 23:218-222. https:/ /doi.org/10.1038/sj.jim.2900726.

Weinberg, Z. G., R. E. Muck, and P. J. Weimer. 2003. The survival of silage inoculant lactic acid bacteria in rumen fluid. J. Appl. Microbiol. 94:1066-1071. https://doi.org/10.1046/j.1365-2672.2003 .01942.x.

Weinberg, Z. G., O. Shatz, Y. Chen, E. Yosef, M. Nikbahat, D. BenGhedalia, and J. Miron. 2007. Effect of lactic acid bacteria inoculants on in vitro digestibility of wheat and corn silages. J. Dairy Sci. 90:4754-4762. https://doi.org/10.3168/jds.2007-0176.

Wilkins, R. J. 2003. Silage: A global perspective. Page 111-132 in Grasslands: Development, Opportunities, Perspectives. S. G. Reynolds and J. Frame, ed. CRC Press.

Wilkinson, J. M., K. K. Bolsen, and C. J. Lin. 2003. History of silage. Pages 1-30 in Silage Science and Technology. D. R. Buxton, R. E. Muck, and J. H. Harrison ed. American Society of Agronomy, Crop Science Society of America, Soil Science Society of America.

Yildirim, M. 2001. Purification of buchnericin LB produced by Lactobacillus buchneri LB. Turk. J. Biol. 25:59-65.

Zhang, F., X. Wang, W. Lu, and C. Ma. 2018. Meta-analysis of the effects of combined homo- and heterofermentative lactic acid bacteria on the fermentation and aerobic stability of corn silage. Int. J. Agric. Biol. 20:1846-1852.

Zielińska, K., A. Fabiszewska, M. Świątek, and D. SzymanowskaPowałowska. 2017. Evaluation of the ability to metabolize 1, 2-propanediol by heterofermentative bacteria of the genus Lactobacillus. Electron. J. Biotechnol. 26:60-63. https://doi.org/10.1016/j.ejbt 2017.01.002.

\section{ORCIDS}

Kathy G. Arriola @ https://orcid.org/0000-0001-6032-8188 André S. Oliveira @ https://orcid.org/0000-0001-9287-0959 Yun Jiang @ C https://orcid.org/0000-0002-4590-2361

Donghyeon Kim ำ https://orcid.org/0000-0003-0756-8419 Henrique M. Silva @ https://orcid.org/0000-0002-8112-9919

Sam Churl Kim @ () https://orcid.org/0000-0003-3105-0118

Felipe X. Amaro @ https://orcid.org/0000-0002-5757-3438

Halima Sultana @ https://orcid.org/0000-0003-3737-1924

Andres A. Pech Cervantes (ㄴ) https://orcid.org/0000-0003-4709-9098

Luiz F. Ferraretto $\odot$ https://orcid.org/0000-0003-4711-8332

Diwakar Vyas ( https://orcid.org/0000-0002-7657-0267

Adegbola T. Adesogan () https://orcid.org/0000-0003-1020-7526 